Article

\title{
Assessing Independent Variables Used in Econometric Modeling Forest Land Use or Land Cover Change: A Meta-Analysis
}

\author{
James A. Jeuck ${ }^{1, *}$, Frederick W. Cubbage ${ }^{2}$, Robert C. Abt ${ }^{2}$, Robert E. Bardon ${ }^{1,2}$, \\ James B. McCarter ${ }^{2}$, John W. Coulston ${ }^{2,3}$ and Mitch A. Renkow ${ }^{4}$ \\ 1 NCSU Extension Forestry, North Carolina State University, Campus Box 8008, Raleigh, \\ NC 27695, USA; E-Mail: rebardon@ncsu.edu
}

2 NCSU Forestry and Environmental Resources, North Carolina State University, Campus Box 8008, Raleigh, NC 27695, USA; E-Mails: fred_cubbage@ncsu.edu (F.W.C); bob_abt@ncsu.edu (R.C.A); james_mccarter@ncsu.edu (J.B.M.); jwcouls1@ncsu.edu (J.W.C.)

3 US Forest Service, 4700 Old Kingston Pike, Knoxville, TN 37919, USA

4 NCSU Agricultural and Resource Economics, Campus Box 8109, Raleigh, NC 27695, USA;

E-Mail: mitch_renkow@ncsu.edu

* Author to whom correspondence should be addressed; E-Mail: jajeuck@ncsu.edu;

Tel.: +1-919-515-5574; Fax: +1-919-515-6889.

Received: 6 March 2014; in revised form: 8 June 2014 / Accepted: 23 June 2014 /

Published: 3 July 2014

\begin{abstract}
We conducted a meta-analysis on 64 econometric models from 47 studies predicting forestland conversion to agriculture (F2A), forestland to development (F2D), forestland to non-forested (F2NF) and undeveloped (including forestland) to developed (U2D) land. Over 250 independent econometric variables were identified from 21 F2A models, 21 F2D models, 12 F2NF models, and 10 U2D models. These variables were organized into a hierarchy of 119 independent variable groups, 15 categories, and 4 econometric drivers suitable for conducting simple vote count statistics. Vote counts were summarized at the independent variable group level and formed into ratios estimating the predictive success of each variable group. Two ratios estimates were developed based on (1) proportion of times the independent variables had statistical significance and (2) proportion of times independent variables met the original study authors' expectations. In F2D models, we confirmed the success of popular independent variables such as population, income, and urban proximity estimates but found timber rents and site productivity variables less successful. In F2A models, we confirmed success of popular explanatory variables such as forest and agricultural rents and costs, governmental programs, and site quality, but
\end{abstract}


we found population, income, and urban proximity estimates less successful. In U2D models, successful independent variables found were urban rents and costs, zoning issues concerning forestland loss, site quality, urban proximity, population, and income. In F2NF models, we found poor success using timber rents but high success using agricultural rents, site quality, population, and income. Success ratios and discussion of new or less popular, but promising, variables was also included. This meta-analysis provided insight into the general success of econometric independent variables for future forest-use or -cover change research.

Keywords: forestland use change; meta-analysis; econometric modeling

\section{Introduction}

Forestland change is ubiquitous across America. Nationally, the 2010 RPA Assessment [1] estimated 41 million acres of additional urban land from 1982 to 2007, a 58\% increase from 1982. The development of forestland contributed to 17 million of those acres (for comparison, this is almost the extent of all North Carolina's timberland). Scenarios in the 2010 RPA Assessment predicted the expansion of urban and developed areas by 2060 will lead to an estimated 16-34 million acres (4\%-8\%) of forestland loss in the contiguous US (this included a predicted 9-21 million acres of forestland development in the US south alone). This has dramatic regional implications on economic and ecosystem services provided by forestland, wildlife habitat, water quality, and carbon sequestration. Conversion of forest use to other uses other than development, even if temporary, inevitably increases soil erosion and water quality degradation. While the past 60 years has seen forestry/agriculture conversions shifting in favor of forestland, over 9 million acres of forestland still have been converted to agriculture in the 1982-2007 period [1].

The need for has never been greater for balancing societal demands with protection of natural forest systems' health, biodiversity, habitat, and ecosystem services. Understanding the dynamics of changing land use and land cover (LULC) is recognized as a critical component in land management planning and policy development. Rural LULC change research has important and direct linkages to natural resource health issues such as forestland conversion [2-6]; crop land abandonment and afforestation [7-9]; agricultural crop support programs [10-13]; and land fragmentation effects on timber base [14]; water quality; and wildlife habitat degradation. Urban LULC change studies explore sprawl and quality of life by modeling growth patterns that reflect zoning, land use regulation policy, urban amenities, and land value [15-29]. Recent studies measure and forecast direct and indirect effects on LULC change through climate change models [10,30-36]. All these efforts are vital for estimated rate of change, forecasting, policy development, and biophysical feedback from the local to global scale. Irwin [37] offers a concise historical perspective of the diverse research efforts in rural development and regional issues.

One important branch of LULC research is identification of econometric variables that can predict forestland change. Stemming from classic Ricardian land rent theory and von Thünen location theory, this research identifies the factors driving ownership decisions to (1) keep lands in "working" forests 
(we define "working" as sustainable performance of normal agricultural management or low to high intensity timber management on forestlands); (2) convert lands to other uses (i.e., forest to agriculture) or (3) permanently remove lands from rural land uses (i.e., forest to development). Since the late 20th century, a profusion of econometric models has developed. These models rely on multivariate regression techniques to predict the extent of land use or land cover change (the dependent variable) based on explanatory variables such as land rent, distance to markets, or population growth. Improvements in tabular and spatial data sources, refined GIS analysis, and innovations in econometric model specifications have resulted in diverse modeling efforts spanning temporal and spatial scales. These studies have employed hundreds of independent variables in efforts to explain land use change. Most studies include important literature reviews that provide background to their research goals and guide future efforts. However, to date there has been no attempt to systematically analyze the wealth of information in the context of describing the types of econometric variables chosen in modeling efforts and their relative success.

\subsection{Vote Counting Meta-Analysis}

The objective of this study was to the review the diverse body of literature on econometric models regarding forest LULC change and devise a method of assessing independent variable success at predicting forestland loss. Our method was based on a vote count meta-analysis of the observed independent variables in each model's results. Vote counting is a simple meta-analysis method appropriate for studies that include a diversity of techniques, data, and assumptions such as those in econometric models of LULC change. This method counts the number of significantly positive, significantly negative, and non-significant correlations that explanatory variables (e.g., land rent or population growth) have with the dependent variable (i.e., forest LULC change). Summing the votes allows an investigator to assess the following:

- popularity of independent variables used in studies;

- success rate of statistical significance for observed independent variables used to predict forestland loss;

- success rate of observed independent variables' sign relationships in meeting the expected relationships of the study authors;

- general relationships and trends drawn from these studies.

Examples of vote counting meta-analysis used in forestry-related econometric studies include Beach et al. [38], who assessed econometric models used in studies of non-industrial private forest management, and Pattanayak et al. [39], who assessed agroforestry adoption studies. Both studies point out that econometric models are not strict experiments and that the results often do not report important assumptions, appropriate error distributions, or even standardized data development. This lack of information precludes the use of more sophisticated meta-analysis forms other than simple vote count procedures. 


\subsection{Determining Vote Count "Success" for Independent Variables Used in Econometric LULC}

\section{Change Studies}

There are numerous ways meta-analysis vote counting may be used to determine the "success" of independent variables' abilities to predict a dependent variable, in this case, forestland loss. The term "success" is subjective and requires contextual framing in terms of the goals and methods used. Our study utilized two definitions to interpret independent variable success. Both methods employed simple vote counts by groups of similar independent variables. Definition No.1 of success followed methods similar to Beach et al. [38] and Pattanayak et al. [39] that were based on vote counts of statistical significance. Our method recognized statistically significant independent variables regardless of unique model conditions that may alter the sign relationship. This recognition was important when working with such a wide diversity of study scales, regional differences, data formats, data resolutions, and research goals. Indeed, the goal of LULC change research often is to identify and estimate previously unknown relationships with no prior stated expectations. Therefore, significance, regardless of sign relationship contributes important information.

We also acknowledged that often LULC change models are developed as the first step in a LULC change forecast model, when researchers are not "exploring data" but have carefully chosen variables with preconceived expectations of their coefficient sign and significance. Numerous studies include these expectations in their methods or results that provide insight into the behavior of the predictive variables given specific model conditions. We recognize there is subjectivity when using the expert opinion of modelers. However, we feel that contrasting the expected and observed behavior of model variables lends additional information when assessing a variable's success for future use. Therefore, for Definition No.2 of success, we provided the proportion of votes when observed sign relationships met expectations to the total number of times relationships were stated for a variable.

\section{Methods}

\subsection{Rules for Model Acceptance}

Over 200 articles were reviewed on LULC change models spanning 35 years of forestry, agricultural, urban, and land planning literature that covered diverse approaches in forestland use change economics. In econometric LULC studies, a wide range of definitions of "forestland" exist [40]. These are based on the study authors' objectives (i.e., strictly rural models vs urban/rural interface models). Even so, we found considerable overlap of the predictive variables due to similarities in many of the processes leading to LULC change. We preferred an inclusive approach to model acceptance in attempts to capture as much overlap as possible. This approach led to the acceptance of a wide variety of definitions of "forestland" within the framework of this study. We accepted four forest LULC change models types based on the "from" and "to" conditions of the model's left hand side (LHS): forest to development (F2D), forest to agriculture (F2A), forest to non-forest (F2NF) and undeveloped to developed (U2D). These are briefly described in Table 1. We originally had two models types (F2D and F2A). Thanks to an anonymous reviewer's advice, we re-assessed the model types and found the F2D model types really were in three distinct types, F2D, $\mathrm{U} 2 \mathrm{D}$, and F2NF. 
Table 1. Brief description of four model types and left hand side (LHS) conditions accepted in meta-analysis of econometric models predicting forest land use and land cover (LULC) change.

\begin{tabular}{cccl}
\hline Model Type & LHS "From" Condition & LHS "to" Condition & \multicolumn{1}{c}{ Comments } \\
\hline F2D & Forestland & Developed/Urban & $\begin{array}{l}\text { Typically specifies forest and urban } \\
\text { from 3 or more possible LHS conditions. }\end{array}$ \\
\hline F2A & Forestland & Agriculture & $\begin{array}{l}\text { Typically specifies forest and agriculture } \\
\text { from 3 or more possible LHS conditions. }\end{array}$ \\
\hline U2D & Undeveloped & Developed/Urban & $\begin{array}{l}\text { Groups forestland, agriculture, and pasture } \\
\text { into undeveloped "from" condition. }\end{array}$ \\
\hline F2NF & Forestland & Non-forested & $\begin{array}{l}\text { Groups agriculture, pasture, and urban into } \\
\text { non-forested "to" condition. }\end{array}$ \\
\hline
\end{tabular}

Of the four model types, F2D and F2A models are the most specific in the "from" and "to" classes. Typically, these were multinomial dependent variable studies predicting three or more possible LULC outcomes (i.e., forest, agriculture and urban). F2NF and U2D models were less specific because of research goals or the model framework and specification. Often, F2NF models were multinomial models but model coefficient results were usually reported only in terms of predicting change in forestland compared to all other uses. U2D models grouped forestland with all other "undeveloped" classes and predicted change to "developed". U2D models were accepted when the authors specifically defined forestland as a major component of the "undeveloped" class. Organizing all models into these four types provided the opportunity to see popular and successful predictive variables by model type and across research objectives.

In general, most of the studies focused on working forestlands (timberlands) and their predicted gains and losses to potential regional timber supply and other ecosystem services. Those studies would employ variables such as timber rents and land productivity to predict forestland change. Other studies, particularly those in the U2D models, had broader definitions of forestland and may not have differentiated between timberland and non-working forestlands in and around urban areas. Variables of commercial timber potential give way to other important considerations such as zoning and urban influences.

Separating the four models also facilitated a more effective meta-analysis process where an important rule was to strive for one-vote per study to eliminate weighting effects. Numerous studies contained both F2D and F2A models in them. Analyzing the four model types separately allowed more than one model to be accepted from a study without violating the one-vote count per study rule.

Other rules of model acceptance were developed to address the one-vote count per study requirement. If the study contained models of different geographic regions, each region's model was accepted. If the study contained multiple model specifications, the model indicated by the authors as the best fit was accepted. If the study contained models predicting different forest types in a single geographic region, the forest type deemed most commercially viable for that region was chosen. Lastly, if the study contained models predicting different ownership classes, non-industrial private forest ownerships was chosen as it represented the largest class in most regions. 


\subsection{Independent Variable Classification and Analytical Framework}

Applying the above rules narrowed the focus to a population of 47 studies with over 250 unique independent variables. First, each accepted model was assigned to one of the four (F2D, F2A, F2NF, U2D) model types and examined for details on model specification, study region and scale, and data resolution. Model dependent and independent variables were examined for data sources and units of scale. As model dependent variables predicted either forestland loss or gain, all observed parameter coefficient signs were standardized so the vote count could be performed correctly. In some studies, authors reversed the ordination of the NRCS Land Capability Class (LCC), a site quality characteristic, while others did not. To standardize this, we reversed the ordination of all studies so that site quality increased with the LCC value. All independent variables, if significant at $p \leq 0.1$, were recorded as positive or negative, otherwise they were recorded as not significant.

To simplify the large number of independent variables, all variables were grouped in a hierarchical classification scheme (See Figure 1). Major drivers in land use change decisions: markets, government policies, site characteristics, and socioeconomics provided the organizational framework. Within the major drivers, categories of variables were developed, such as timber rents within market drivers (Figure 1). A variety of independent variables representing forms of timber rents required further grouping within the timber rents category. The "independent variable groups" level is where vote counting occurred. Figure 1 shows a small portion of all F2A models, listing studies that used soil expectation value (SEV) of sawtimber as an independent variable. All SEV variables across F2A models were similar enough to be vote counted in "Independent Variable Group 1: Soil Expectation Value, all sawtimber".

Figure 1. Example of groupings of the F2A models used for vote count meta-analysis of econometric independent variables predicting forestland loss.

Market Drivers

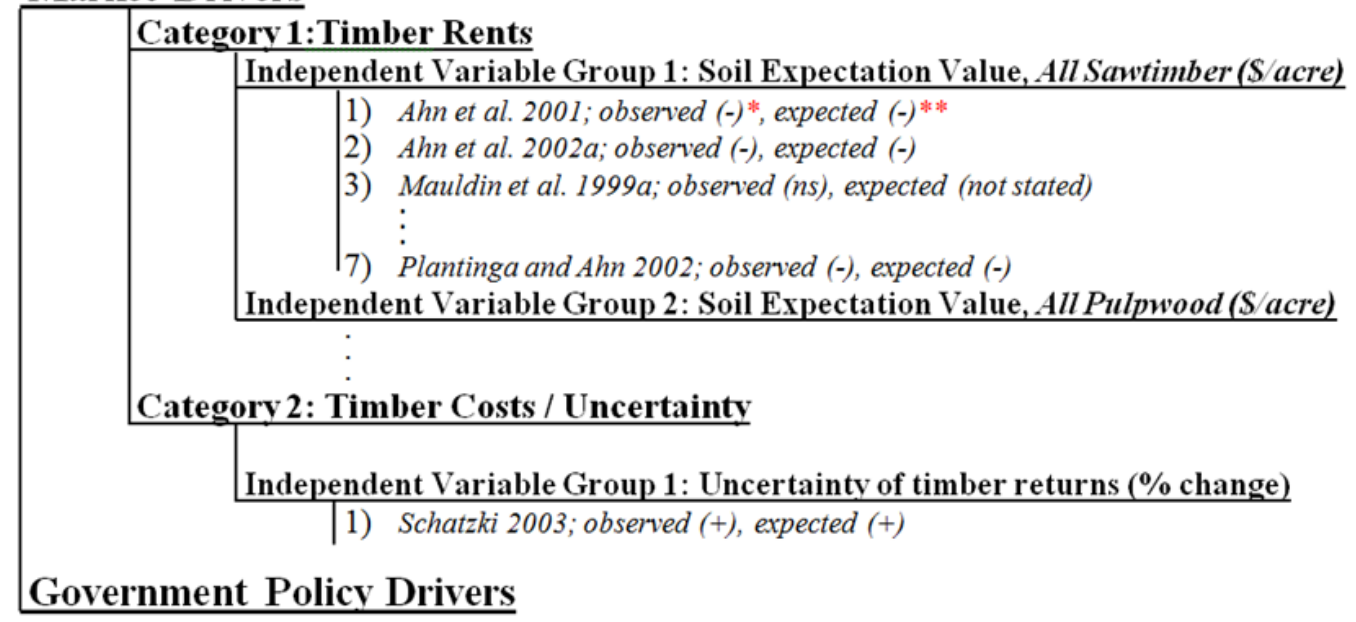

\footnotetext{
* observed is the observed relationship the model independent variable and forestland loss as recorded in the study. Positive and negative relationships were included only if obtained statistical significance of $p=0.10$ or less, otherwise " $n$ " = not significant; ** expected is the expected sign relationship for the independent variable if stated in the study, otherwise "not stated".
} 
The success of each independent variable was then assessed and tallied based on the two success definitions described above. Conceptually, within Independent Variable Group 1, the "Ahn et al. 2001" study was given the assignment "observed (-)". This was the vote based on the observed regression coefficient for SEV. The "success" Definition No.1 stated earlier (observed statistical significance regardless of sign) was basis for this vote and it received vote of " 1 ". The assignment, expected (-), denotes the study authors stated that they expected this variable to have a negative relationship in their F2A model. Thus, the variable received a vote of " 1 " on the basis of the "success" Definition No.2 (observed significant relationship met expectations). While not a rigorous examination, vote count based on the independent variable group-level was useful in drawing observations and conclusions about the relative success of categories and independent variable groups.

To include "positive", "negative", and "not significant" vote counts, along with study authors' citations for each independent variable group, proved too unwieldy to include in this paper. Instead, we summarized "success" using the two definitions provided earlier. Definition No.1, significance regardless of the independent variables' sign relationships to forestland loss, was expressed using the following ratio:

$$
S / T=\frac{\sum S_{i}}{n_{i}}
$$

where: $\sum S_{i}=$ vote count sum for observed significant variable coefficients in independent variable group $(i) ; n_{i}=$ number of independent variables in group (i).

Definition \#2, meeting the authors' expected sign relationships between independent variables and forestland loss, was expressed using the following ratio:

$$
E / T=\frac{\sum \text { OEAgree }_{i}}{n e_{i}}
$$

where: $\sum \mathrm{O}$ EAgree $_{i}=$ vote count sum of observed significant variable coefficients for independent variable group $(i)$ that agreed with the study authors' expectations in group $(i)$ $n e_{i}=$ number independent variables in group $(i)$ with stated expectations.

$\mathrm{S} / \mathrm{T}$ and $\mathrm{E} / \mathrm{T}$ ratios of vote counts were performed at the independent variable group level and summarized at the category level. High $\mathrm{S} / \mathrm{T}$ ratios suggest success of the members in an independent variable group's ability to achieve statistical significance in predicting forestland loss for a particular model type. High E/T ratios suggest that members in an independent variable group adhered expectations for a particular model type.

\section{Results}

\subsection{Accepted Models Description}

For brevity, the results presented here are only summaries of the datasets created from this analysis. We have provided a thorough dataset accompanying this study that may be downloaded by anyone requiring a more detailed examination of the data. After careful review, a population of 64 models from 47 studies was accepted. Table 2 lists each study by model type (F2D, F2A, F2NF, U2D) lead author(s), dependent variable (LHS), model specification, and geographic region. The earliest model 
accepted was White and Flemming [41] and most recent was Meng [42]. The observed models used change data spanning over 70 years with individual studies ranging from 2-year to 45-year periods. Ten studies contained both F2D and F2A model types and one study contained both F2NF and F2A models.

Table 2. Characteristics of 47 econometric studies used in this meta-analysis by forest LULC change models, authors, dependent variable, and model specification. The LULC change model types studied were forest to agriculture (F2A, 21 models), forest to development (F2D, 21 models), undeveloped to developed (U2D, 10 models), and forest to non-forest (F2NF, 12 models). (LC) identifies the 6 land cover change models, all others were land use change models.

\begin{tabular}{|c|c|c|c|c|}
\hline Model Type & Authors & Dependent Variable Estimator (LHS) & $\begin{array}{c}\text { Model } \\
\text { Specification } \\
\end{array}$ & Region \\
\hline FA2 & Claassen 1993 [43] & probability: farm conversion to forest & conditional logit & South \\
\hline FA2 & Jensen 2007 [44] & $\log$ acres CRP & OLS & South \\
\hline FA2 & Parks and Kramer 1995 [10] & proportion: county land in WRP & grouped logit & National \\
\hline FA2 & Parks and Schorr 1997 [45] & area enrolled in CRP & grouped logit & Northeast \\
\hline FA2 & Poe 1998 [46] & proportion: state hydric cropland in WRP & OLS & National \\
\hline FA2 & Schatzki 2003 [47] & probability: NRI crop plot to forest & binomial probit & South \\
\hline F2A & Stavins and Jaffe 1990 [48] & forest from crop land abandonment & nonlinear LS & South \\
\hline $\mathrm{F} 2 \mathrm{~A}$ & White and Flemming 1980 [41] & forest acres $v s$ crop acres & OLS (3-stage) & South \\
\hline F2D & Ahn et al. 2002b [49] & $\ln ($ urban share/forest share) & MML & South \\
\hline F2D, LC & Hodges et al. 1998 [50] & binary: LC pixel change forest to urban & binomial logit & South \\
\hline F2D, LC & Kline et al. 2009 [51] & logit(developed from LC forest pixel) & Logit & West \\
\hline $\mathrm{F} 2 \mathrm{D}$ & Nagubadi and Zhang 2005 [52] & $\ln ($ timberland share/urban and other share) & MML & South \\
\hline F2D & Nagubadi and Zhang 2007 [53] & $\ln (\mathrm{SW}$ forest share/urban and other share) & MML & South \\
\hline F2D & Nagubadi and Zhang 2009 [54] & $\ln ($ NIPF share/urban and other share) & MML & South \\
\hline F2D & Nagubadi and Zhang 2010 [55] & $\ln$ (timberland forest share/urban share) & MML & South \\
\hline F2D, LC & Wear and Bolstad $1999^{2}[56]$ & probability: LC forested pixel developed & binomial logit & South \\
\hline F2D & Zhang and Nagubadi 2005 [57] & $\ln$ (timberland share/urban and other share) & MML & South \\
\hline $\mathrm{F} 2 \mathrm{D}, \mathrm{F} 2 \mathrm{~A}$ & Ahn et al. 2000 [58] & $\begin{array}{c}\ln (\text { urban share/forest share) } \\
\ln (\text { agriculture share/forest share) }\end{array}$ & MML & South \\
\hline $\mathrm{F} 2 \mathrm{D}, \mathrm{F} 2 \mathrm{~A}$ & Ahn et al. 2001 [2] & $\begin{array}{c}\ln (\text { urban share/forest share) } \\
\ln \text { (agriculture share/forest share) }\end{array}$ & MML & South \\
\hline F2D, F2A & Ahn et al. 2002a [59] & $\begin{array}{c}\ln (\text { urban share/forest share) } \\
\ln \text { (agriculture share/forest share) }\end{array}$ & MML & South \\
\hline $\mathrm{F} 2 \mathrm{D}, \mathrm{F} 2 \mathrm{~A}$ & Lubowski 2002 [12] & $\begin{array}{c}\text { probability: NRI forest plot to urban } \\
\text { probability: NRI forest plot to agriculture }\end{array}$ & nested logit & National \\
\hline $\mathrm{F} 2 \mathrm{D}, \mathrm{F} 2 \mathrm{~A}$ & Mauldin et al. 1999a [60] & $\begin{array}{l}\text { ln (urban share/forest share) } \\
\ln \text { (farm share /forest share) }\end{array}$ & MML & Northeast \\
\hline $\mathrm{F} 2 \mathrm{D}, \mathrm{F} 2 \mathrm{~A}$ & Mauldin et al. 1999b [61] & $\begin{array}{l}\ln \text { (urban share/forest share) } \\
\ln \text { (farm shares/forest shares) }\end{array}$ & MML & Midwest \\
\hline
\end{tabular}


Table 2. Cont.

\begin{tabular}{|c|c|c|c|c|}
\hline Model Type & Authors & Dependent Variable Estimator (LHS) & $\begin{array}{c}\text { Model } \\
\text { Specification } \\
\end{array}$ & Region \\
\hline $\mathrm{F} 2 \mathrm{D}, \mathrm{F} 2 \mathrm{~A}$ & Munn and Cleaves 1999 [3] & $\begin{array}{l}\text { probability: FIA forest plot to urban } \\
\text { probability: FIA forest plot to agri. }\end{array}$ & ML & South \\
\hline F2D, F2A & $\begin{array}{l}\text { Plantinga and Mauldin } 2001^{3} \\
\qquad[32]\end{array}$ & $\begin{array}{l}\ln (\text { urban share/forest share) } \\
\ln (\text { farm share/forest share) }\end{array}$ & MML & $\begin{array}{l}\text { Midwest, } \\
\text { South, } \\
\text { Northeast }\end{array}$ \\
\hline $\mathrm{F} 2 \mathrm{D}, \mathrm{F} 2 \mathrm{~A}$ & Polyakov and Zhang 2007 [62] & $\begin{array}{l}\text { probability: NRI forest plot to urban } \\
\text { probability NRI forest plot to farm }\end{array}$ & nested logit & South \\
\hline $\begin{array}{l}\text { F2D, F2A, } \\
\text { LC }\end{array}$ & Polyakov and Zhang 2008 [63] & $\begin{array}{l}\text { probability: LC forest pixel converts } \\
\text { to development probability LC forest } \\
\text { pixel converts to farm }\end{array}$ & conditional logit & South \\
\hline $\mathrm{F} 2 \mathrm{NF}$ & Alig et al. $1988^{4}[64]$ & percent farm-forestland share-Coastal Plain & SURE & South \\
\hline F2NF & Alig $1986^{5}[65]$ & percent farm-forestland share & SURE & South \\
\hline F2NF & Hardie and Parks 1997 [66] & $\ln [\mathrm{P}($ forest $) / \mathrm{P}($ developed $)]$ & MML & South \\
\hline F2NF & Hardie et al. 2000 [67] & $\ln [(\mathrm{P}($ forest $) / \mathrm{P}($ developed $)]$ & MML & South \\
\hline $\mathrm{F} 2 \mathrm{NF}$ & Lewis and Plantinga 2007 [68] & probability: NRI plot transition from forest & conditional logit & South \\
\hline $\mathrm{F} 2 \mathrm{NF}$ & Meng 2011 [42] & probability: NRI plot transition from forest & RP logit & South \\
\hline F2NF & Parks and Murray $1994^{6}[69]$ & proportion of county in forestland & grouped logit & West \\
\hline $\mathrm{F} 2 \mathrm{NF}$ & Plantinga and $\mathrm{Wu} 2003$ [33] & $\ln ($ forested share/non-forest share $)$ & SURE & Midwest \\
\hline $\mathrm{F} 2 \mathrm{NF}$ & Wear et al. $1999[70]$ & $\begin{array}{l}\text { probability: transition } \\
\text { from commercial forestry }\end{array}$ & binomial logit & South \\
\hline $\mathrm{F} 2 \mathrm{NF}, \mathrm{A} 2 \mathrm{~F}$ & Plantinga and Ahn 2002 [71] & $\begin{array}{l}\text { probability: forest to non-forest transition } \\
\text { probability: farm to forest transition }\end{array}$ & NSURE & South \\
\hline $\mathrm{U} 2 \mathrm{D}$ & Alig et al. 2004 [72] & $\ln [\mathrm{P}($ developed $) / 1-\mathrm{P}($ undeveloped $)]$ & logit & National \\
\hline U2D, LC & Alig et al. 2005 [14] & forest fragmentation index & OLS & West \\
\hline U2D & Bockstael 1996 [73] & binary: undeveloped $v s$ developed & binomial probit & Northeast \\
\hline $\mathrm{U} 2 \mathrm{D}$ & Carrion and Irwin 2004 [16] & probability: undeveloped to residential & binomial probit & Midwest \\
\hline $\mathrm{U} 2 \mathrm{D}$ & Cho et al. $2005^{7}[24]$ & $\log$ (developed/original undeveloped area) & SURE & West \\
\hline $\mathrm{U} 2 \mathrm{D}$ & Hsieh et al. 2000 [17] & acres undeveloped converted to urban & 2-Stage OLS & Midwest \\
\hline $\mathrm{U} 2 \mathrm{D}$ & Irwin et al. 2002 [74] & $\ln$ (undeveloped share/developed share) & binomial probit & Midwest \\
\hline $\mathrm{U} 2 \mathrm{D}$ & Irwin and Bockstael 2002 [75] & binary: undeveloped parcel gets developed & binomial probit & Northeast \\
\hline $\mathrm{U} 2 \mathrm{D}$ & Kline and Alig 1999 [76] & probability: FIA forest plot is converted & binomial probit & West \\
\hline U2D, LC & Landis and Zhang 1997 [77] & $\begin{array}{l}\text { probability: LC undeveloped pixel } \\
\text { to developed }\end{array}$ & ML & West \\
\hline
\end{tabular}

${ }^{1}$ ML denotes multinomial logit, MML denotes modified multinomial logit, RP logit denotes random parameter logit, OLS denotes ordinary least squares, SURE denotes seemingly unrelated regression equation, NSURE denotes non-linear seemingly unrelated regression equations; ${ }^{2}$ Wear and Bolstad (1999) [56] had three study areas from the Southern Appalachian. We chose only one, Henderson County, NC; ${ }^{3}$ Plantinga and Mauldin (2001) [32] had three study states that we treated separately: Wisconsin, Maine, and South Carolina; ${ }^{4}$ Alig et al. (1988) [64] had two study areas that we treated separately: Southern Coastal Plain, and Southern Interior Highlands; ${ }^{5}$ Alig (1986) [65] study modeled multiple areas in the US South but we only used the one covering the full extent; ${ }^{6}$ Parks and Murray (1994) [69] had two study states that we treated separately: Oregon and Washington; ${ }^{7}$ Cho et al. (2005) [24] modeled the east and west sides of the Cascades region separately along with a pooled model. We chose only the pooled model. 
Six studies (labeled with "LC" in Table 2) used land cover change models as the dependent variable. Land cover models are derived from remotely sensed "snapshots" of land cover and, depending on the classification techniques used, may not detect normal forest harvesting from land conversion activities. This could lead to erroneous estimates of true land use change (Coulston et al. [78], Hodges et al. [50], Polyakov and Zhang [63]). However, when land cover models are thoroughly ground-truthed and misclassifications corrected, they have the advantage of complete coverage of the study region. With the exception of Alig et al. [14], all the land cover models included in this meta-analysis claimed some form of validation and/or reclassification technique accounting for young forests. The remaining 41 studies used land use change originating from inventory plot-, parcel-, county-, or state-level data as the dependent variable. Six studies modeled multiple regions. The footnotes for Table 2 describe our decisions regarding these studies in attempting not to violate the one-vote per study rule.

The spatial resolution of dependent variables were graphed by model type and geographic region (Figure 2). Pixel data refers to satellite imagery. Plot data typically came from the USFS Forest and Inventory and Analysis (FIA) or the USDA Natural Resources Inventory (NRI) datasets. Parcel data usually came from land records offices and were found on studies covering relatively small geographic areas. The most commonly used spatial resolution was county-level (64\% of all studies). For simplification of Figure 2, two other resolutions were grouped along with the county-level data, Census Tracts ( 2 studies) and FIA units (4 studies). Typically county-level models predicted the change in proportions (termed "shares", Table 2) of various land uses at the county level. FIA and NRI plot data was frequently aggregated at the county level; however, seven studies modeled change of the NRI or FIA plots. These can be determined in Table 2 in the "Dependent Variable Estimator (LHS)" column. By doing so, these studies took advantage of important site productivity information such as Land Capability Class (NRI) or Site Index (FIA) included in plot inventory data. Lubowski [12] found NRI plots the best data source for his nationwide study on land use change predictions.

Figure 2. Spatial resolutions by geographic region and model types included in a meta-analysis of 64 econometric models predicting forestland conversion.

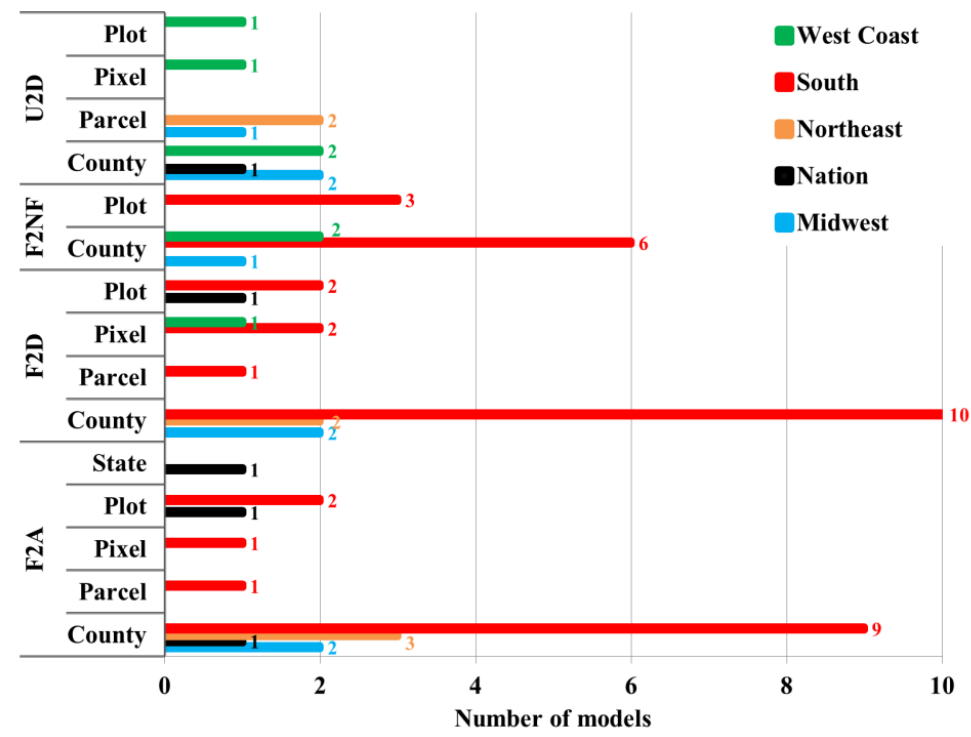

Notes: pixel denotes satellite imagery data, plot denotes FIA or NRI inventory plot, parcel denotes property parcel. 
The F2D and F2A model types were most frequent, each having 21 models (33\%). The number of remaining model types ranged from five to eight. Figure 2 shows the models were highly skewed to the US South with 37 models (58\%). Most research interest in this region centered on agriculture/forest conversion predictions and loss of productive forestland (and their benefits such as wildlife habitat) to development. U2D processes are typically accounted for in F2D studies, perhaps demonstrated by the lack of specific U2D studies in the US South. Forestland conversion to agriculture is not as prevalent an issue in other regions (i.e., northeast) relative to the US South and received less emphasis. West Coast research that we used focused more on permanent development of rural land rather than specific forest to agriculture processes. The other geographic regions showed consistent use of all four model types.

Figure 3 groups model specifications by model type and geographic region. The three most common specification groups were logit (9 specification forms); ordinary least squares (OLS, 3 specification forms), and seemingly unrelated regression equations (SURE, 2 specification forms). Logit models represented $80 \%$ of all models with binomial or multinomial dependent variables and were used across all model types and geographic regions.

Figure 3. Model specifications by geographic region and model types included in a meta-analysis of 64 econometric models predicting forestland conversion.

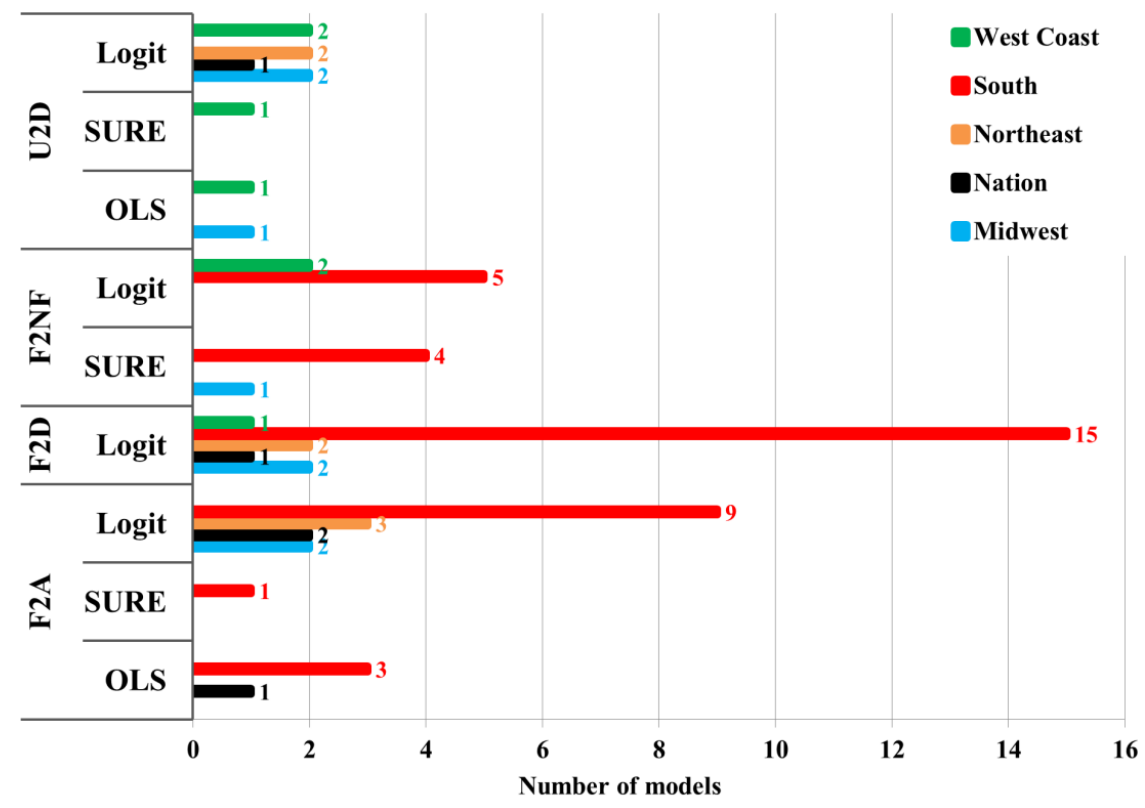

\subsection{Frequency of Model Use by Econometric Drivers and Categories}

All variables were organized into 4 major drivers: markets, government policies, site characteristics, and socioeconomic characteristics. These drivers were further classified into 15 categories. Table 3 provides a brief description/justification of the rich variety of modeling categories in these studies. Figure 4 provides a graphic of the frequency (popularity) of econometric drivers and categories used by model type. Land productivity was the most popular category and used in high proportions of all model types. Similarly population ranked very high among all model types. Rents (timber and agricultural) were most popular with F2A, F2D, and F2NF models. Proximity to development had 
relatively high popularity in F2D and U2D models and to a lesser extent F2A models. Forestry incentive programs were important in F2A models and zoning of interest in F2NF models.

Table 3. Description of 15 categories used to organize variables from 64 econometric models for use in vote count summaries.

\begin{tabular}{|c|c|c|}
\hline Driver & Category & Description \\
\hline \multirow{6}{*}{ Market } & Timber Rents & Income from forest production or economic value of timber (price, etc.) \\
\hline & $\begin{array}{l}\text { Timber } \\
\text { Costs/Uncertainty }\end{array}$ & $\begin{array}{l}\text { Costs involved in timber production (i.e., site preparation costs) or } \\
\text { indicators of uncertainty in timber product (i.e., uncertainty in } \\
\text { timber revenue) }\end{array}$ \\
\hline & Agriculture Rents & Income from agricultural production \\
\hline & $\begin{array}{l}\text { Agriculture } \\
\text { Uncertainty }\end{array}$ & $\begin{array}{l}\text { Costs involved in agricultural production (i.e., cropping costs), } \\
\text { indicators of uncertainty in agricultural product (i.e. uncertainty in } \\
\text { agriculture revenue), or practices that reduce uncertainty in } \\
\text { agriculture (i.e., irrigation systems) }\end{array}$ \\
\hline & Urban Rents & Income from development or residential land value \\
\hline & $\begin{array}{l}\text { Urban } \\
\text { Costs/Uncertainty }\end{array}$ & $\begin{array}{l}\text { Costs involved in development (i.e., conversion costs, property } \\
\text { taxes), indicators of uncertainty in development markets (i.e., } \\
\text { variance of housing values), or practices that reduce uncertainty for } \\
\text { development (i.e., sewers nearby) }\end{array}$ \\
\hline \multirow{2}{*}{$\begin{array}{l}\text { Government } \\
\text { Policy }\end{array}$} & $\begin{array}{l}\text { Forestry Incentive } \\
\text { Programs }\end{array}$ & $\begin{array}{l}\text { Involving government programs promoting forestry, effects of } \\
\text { government programs that promote agriculture. }\end{array}$ \\
\hline & $\begin{array}{l}\text { Zoning Effects on } \\
\text { Forestland Loss }\end{array}$ & $\begin{array}{l}\text { Involves effects of forest/agriculture use zones, urban growth zones, } \\
\text { critical habitat zones, mandatory review of farmland development, } \\
\text { rural zoning at the county Vs township levels (and spillover effects) }\end{array}$ \\
\hline \multirow{4}{*}{$\begin{array}{c}\text { Site } \\
\text { Characteristics }\end{array}$} & $\begin{array}{l}\text { Land } \\
\text { Quality/Productivity }\end{array}$ & $\begin{array}{l}\text { Site productivity ratings for agriculture or forestry, land quality } \\
\text { fragmentation. Also, land quality for development, slope, and } \\
\text { elevation. }\end{array}$ \\
\hline & $\begin{array}{l}\text { Forestland } \\
\text { Proximity } \\
\text { Influences }\end{array}$ & $\begin{array}{l}\text { Status of location with respects to timber production/ownerships } \\
\text { (i.e., forest type, ownership type, or contiguous forestland } \\
\text { surrounding location). }\end{array}$ \\
\hline & $\begin{array}{l}\text { Agricultural } \\
\text { Proximity } \\
\text { Influences }\end{array}$ & $\begin{array}{l}\text { Status of location with respects to agriculture } \\
\text { production/ownerships (i.e. farmer owned, acres of farmland in } \\
\text { county). }\end{array}$ \\
\hline & $\begin{array}{l}\text { Development } \\
\text { Proximity } \\
\text { Influences }\end{array}$ & $\begin{array}{l}\text { Status of location with respects to development potential (distance } \\
\text { to roads, cities, developed sites, vacant land, etc.). Also includes } \\
\text { USDA Economic Research or other combinations of distance and } \\
\text { population measurements yielding "gravity" indices, or "urban } \\
\text { continuity" }\end{array}$ \\
\hline \multirow{3}{*}{ Socioeconomic } & $\begin{array}{l}\text { Population and } \\
\text { Growth }\end{array}$ & $\begin{array}{l}\text { US Census Bureau estimates of population, typically county } \\
\text { density. }\end{array}$ \\
\hline & Income & US Census Bureau estimates of income, typically median $\mathrm{HH}$. \\
\hline & $\begin{array}{c}\text { Other } \\
\text { Socioeconomic }\end{array}$ & $\begin{array}{l}\text { Includes landowner age, education, death rates, and effects of } \\
\text { changes in estate tax laws. }\end{array}$ \\
\hline
\end{tabular}


Figure 4. Frequency of models by major econometric driver and categories included in a meta-analysis of 64 econometric models predicting forestland conversion.

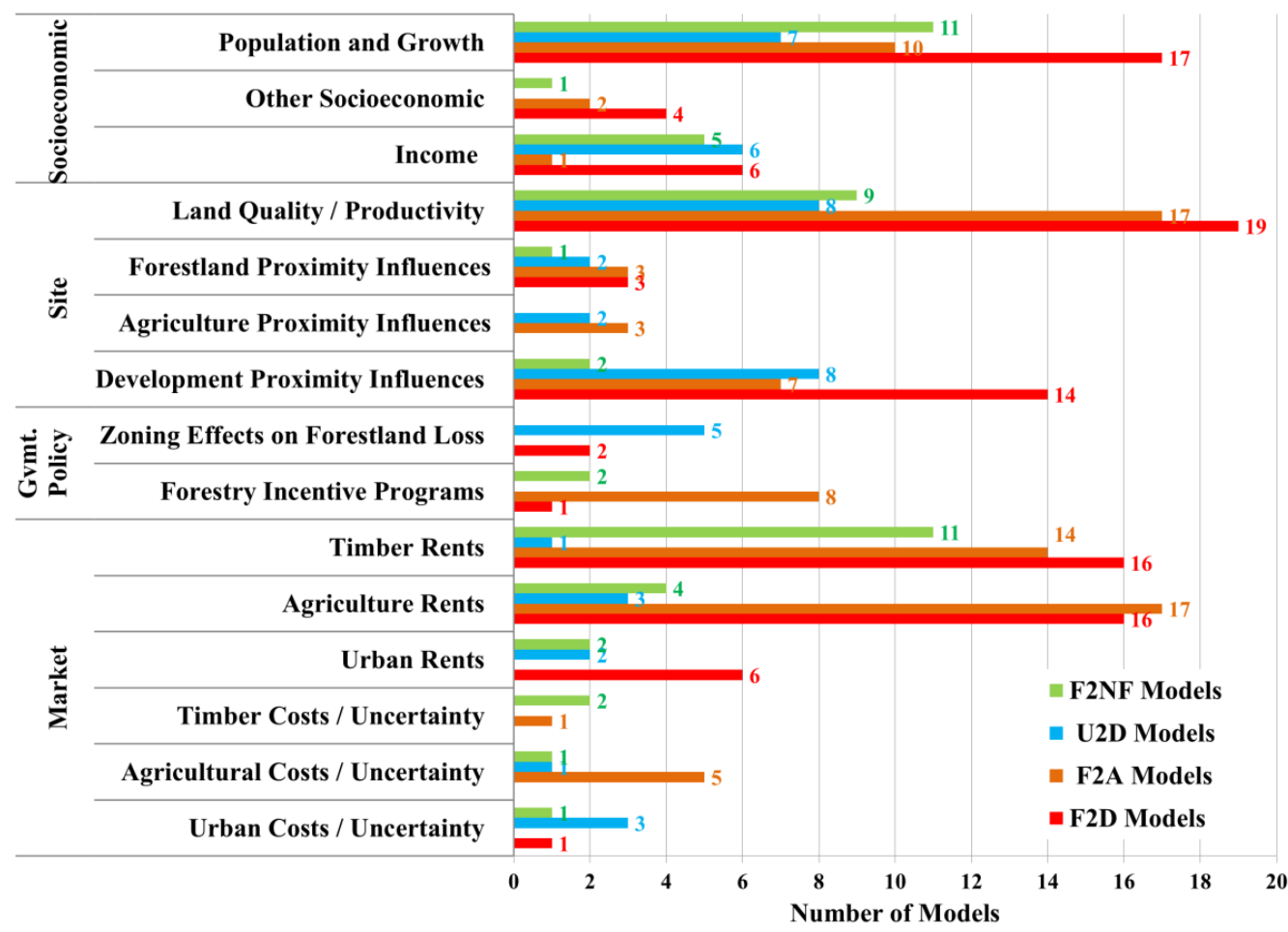

\subsection{Vote Count Analysis Results}

Table 4 is the summarized vote count ratios for the 64 models. It was organized by the four model types (columns) and econometric drivers, categories, and independent variable groups (rows). The category name rows also include the number of models used for that category by model type. For example, 16 F2D models used variables in the timber rents category $(m=16)$. Within each category are the independent variable groups and their estimation units. The 113 independent variable groups attested to the diversity and imagination study authors. Each model type has two columns containing the vote count ratios, "S/T" (significant to total) and "E/T" (expected to total) described by success Definitions No.1 (Equation (1)) and No.2 (Equation (2)).

The "category summary" row, allows quick assessment of the overall success of a category. Frequently, these summaries were larger than the number of models. This resulted from models that contained multiple variables within a category. For example, Nagubadi and Zhang [53] included sawtimber prices of both oak and pine in the F2D model that we chose. Both variables fell under the same category but were in different independent variable groups. The far right column (All $\mathrm{S} / \mathrm{T})$ is the summary of $\mathrm{S} / \mathrm{T}$ ratios for all model types. An important point when interpreting the All $\mathrm{S} / \mathrm{T}$ column is double counts occurred for certain variables. This results when a study had two model types (as the case with 10 F2D and F2A models) that used the same variable.

We provided a lower limit to "success" at $67 \%$ and visually marked ratios falling below that in yellow for $\mathrm{S} / \mathrm{T}$ ratios and orange for $\mathrm{E} / \mathrm{T}$ ratios. While admittedly an arbitrary limit, this highlighted the independent variable groups that may warrant caution. 
Table 4. Vote count meta-analysis summary of independent variables used in 47 econometric studies that estimated forest land loss through 4 model types: forest to development models (F2D), forest to agriculture models (F2A), undeveloped to developed models (U2D), and forested to non-forested models (F2NF).

\begin{tabular}{|c|c|c|c|c|c|c|c|c|c|}
\hline & \multicolumn{2}{|c|}{ F2D } & \multicolumn{2}{|c|}{ F2A } & \multicolumn{2}{|c|}{ U2D } & \multicolumn{2}{|c|}{ F2NF } & \multirow{2}{*}{$\begin{array}{l}\text { All } \\
\text { S/T }\end{array}$} \\
\hline & $\mathrm{S} / \mathrm{T}$ & $\mathrm{E} / \mathrm{T}$ & $\mathrm{S} / \mathrm{T}$ & $\mathrm{E} / \mathrm{T}$ & $\mathrm{S} / \mathrm{T}$ & $\mathrm{E} / \mathrm{T}$ & $\mathrm{S} / \mathrm{T}$ & $\mathrm{E} / \mathrm{T}$ & \\
\hline \multicolumn{10}{|l|}{ Market Drivers } \\
\hline Timber Rents & \multicolumn{2}{|c|}{$m=16$} & \multicolumn{2}{|c|}{$m=14$} & \multirow{2}{*}{\multicolumn{2}{|c|}{$m=1$}} & \multicolumn{2}{|c|}{$m=11$} & $m=36$ \\
\hline Soil Expectation Value, Sawtimber, All (\$/acre) & $3 / 8$ & $2 / 3$ & $8 / 10$ & $8 / 8$ & & & $3 / 4$ & $2 / 4$ & $14 / 22$ \\
\hline Soil Expectation Value, Pulpwood All (\$/acre) & $1 / 1$ & $1 / 1$ & $1 / 1$ & $1 / 1$ & & & & & $2 / 2$ \\
\hline Timber Products Income (\$/county) & $2 / 2$ & $2 / 2$ & $3 / 3$ & $3 / 3$ & & & $1 / 3$ & & $6 / 8$ \\
\hline Stumpage Value Sawtimber, All (\$/MBF) & $5 / 5$ & $4 / 4$ & & & & & $1 / 1$ & $1 / 1$ & $6 / 6$ \\
\hline Forestry : Crop Income Rent (ratio) & & & & & & & $1 / 3$ & $1 / 2$ & $1 / 3$ \\
\hline Pulpwood Stumpage Price, Softwood (\$/unit) \$/cu ft) & & & & & & & $1 / 1$ & & $1 / 1$ \\
\hline Sawtimber Stumpage Price Softwoods (\$/MBF)] & $1 / 1$ & $1 / 1$ & $1 / 1$ & $1 / 1$ & $0 / 1$ & & $1 / 2$ & $1 / 1$ & $3 / 5$ \\
\hline Stumpage Value Sawtimber, Oak (\$/MBF) & $0 / 1$ & $0 / 1$ & & & & & & & $\mathbf{0} / \mathbf{1}$ \\
\hline Category Summary & $12 / 18$ & & $13 / 15$ & & $1 / 1$ & & $8 / 14$ & & $33 / 48$ \\
\hline Timber Costs/Uncertainty & \multicolumn{2}{|c|}{$m=0$} & \multicolumn{2}{|c|}{$m=1$} & & & \multicolumn{2}{|c|}{$m=2$} & $m=\mathbf{3}$ \\
\hline Timber Site Prep/Planting Costs (\$/acre) & & & & & & & $1 / 2$ & $1 / 1$ & $1 / 2$ \\
\hline Trend in timber returns (returns trend line) & & & $0 / 1$ & & & & & & $\mathbf{0} / \mathbf{1}$ \\
\hline Uncertainty of Timber Revenue (derived) & & & $1 / 1$ & $1 / 1$ & & & & & $1 / 1$ \\
\hline Category Summary & & & $1 / 2$ & & & & $1 / 2$ & & $2 / 4$ \\
\hline Agriculture Rents & \multicolumn{2}{|c|}{$m=16$} & \multicolumn{2}{|c|}{$m=17$} & \multicolumn{2}{|c|}{$m=\mathbf{3}$} & \multicolumn{2}{|c|}{$m=4$} & $m=34$ \\
\hline County Level Farm Rent (SEV or Profit) (\$/acre) & $1 / 2$ & $0 / 1$ & $7 / 7$ & $7 / 7$ & & & $2 / 2$ & $1 / 1$ & $10 / 11$ \\
\hline County Farm Prod. Rev., \$ Total or Net/area) & $2 / 13$ & $4 / 4$ & $7 / 9$ & $7 / 9$ & $2 / 3$ & & $1 / 2$ & $1 / 2$ & $12 / 27$ \\
\hline Farm Income to State Per Capita Income (ratio) & & & $1 / 1$ & $1 / 1$ & & & & & $1 / 1$ \\
\hline Proportion of sales from high-value crops (ratio) & & & $1 / 1$ & $1 / 1$ & & & & & $\mathbf{1} / \mathbf{1}$ \\
\hline
\end{tabular}


Table 4. Cont.

\begin{tabular}{|c|c|c|c|c|c|c|c|c|c|}
\hline & \multicolumn{2}{|c|}{ F2D } & \multicolumn{2}{|c|}{ F2A } & \multicolumn{2}{|c|}{ U2D } & \multicolumn{2}{|c|}{ F2NF } & \multirow{2}{*}{$\begin{array}{c}\text { All } \\
\text { S/T }\end{array}$} \\
\hline & $\mathrm{S} / \mathrm{T}$ & $\mathrm{E} / \mathrm{T}$ & $\mathrm{S} / \mathrm{T}$ & $\mathrm{E} / \mathrm{T}$ & $\mathrm{S} / \mathrm{T}$ & $\mathrm{E} / \mathrm{T}$ & $\mathrm{S} / \mathrm{T}$ & $\mathrm{E} / \mathrm{T}$ & \\
\hline Category Summary & $3 / 16$ & & $16 / 18$ & & $2 / 3$ & & $3 / 4$ & & $24 / 40$ \\
\hline Agricultural Costs/Uncertainty & \multicolumn{2}{|c|}{$m=0$} & \multicolumn{2}{|c|}{$m=5$} & \multicolumn{2}{|c|}{$m=1$} & \multicolumn{2}{|c|}{$m=1$} & $m=7$ \\
\hline County (or Parcel) Crop Costs (\$/acre) & & & $2 / 3$ & $2 / 3$ & & & $0 / 1$ & & $2 / 4$ \\
\hline Uncertainty of Agriculture Revenue (derived) & & & $1 / 1$ & $1 / 1$ & & & & & $1 / 1$ \\
\hline Conservation Practices Used on Plot (binary) & & & $1 / 1$ & $1 / 1$ & & & & & $1 / 1$ \\
\hline Conversion Costs Forest to Agriculture $(\$)$ & & & $2 / 2$ & $2 / 2$ & & & & & $2 / 2$ \\
\hline Property Taxes (\$) & & & $1 / 1$ & $1 / 1$ & & & & & $1 / 1$ \\
\hline Trend in Agriculture Revenue ( $\%$ change) & & & $0 / 1$ & & & & & & $\mathbf{0} / \mathbf{1}$ \\
\hline Irrigation (binary) & & & $1 / 1$ & $1 / 1$ & & & & & $1 / 1$ \\
\hline Uncertainty of Agriculture Revenue (derived) & & & $\mathbf{1} / \mathbf{1}$ & $1 / 1$ & $\mathbf{1} / \mathbf{1}$ & $1 / 1$ & & & $2 / 2$ \\
\hline Category Summary & & & $8 / 10$ & & $1 / 1$ & & $0 / 1$ & & $9 / 12$ \\
\hline Urban Rents & & & $m$ & & & & & & $m=9$ \\
\hline Residential Land Value (\$/acre) & & & & & $1 / 1$ & $1 / 1$ & & & $1 / 1$ \\
\hline Profit from Recently Developed Land (\$/county) & $6 / 6$ & $6 / 6$ & & & $1 / 1$ & $1 / 1$ & $2 / 2$ & & $9 / 9$ \\
\hline Category Summary & $6 / 6$ & & & & $2 / 2$ & & $2 / 2$ & & $10 / 10$ \\
\hline Urban Costs/Uncertainty & & & $m$ & & & & & & $m=5$ \\
\hline Value of Farmland (\$) & & & & & $2 / 2$ & $2 / 2$ & $0 / 1$ & & $2 / 3$ \\
\hline Conversion Cost Forest to Urban $(\$)$ & $1 / 1$ & $1 / 1$ & & & $1 / 1$ & $1 / 1$ & & & $2 / 2$ \\
\hline Property Taxes $(\$)$ & $1 / 1$ & $1 / 1$ & & & & & & & $1 / 1$ \\
\hline Sewer nearby (binary) & & & & & $1 / 1$ & $1 / 1$ & & & $1 / 1$ \\
\hline Variance of new housing value (derived) & & & & & $1 / 1$ & $1 / 1$ & & & $1 / 1$ \\
\hline Category Summary & $2 / 2$ & & & & $5 / 5$ & & $0 / 1$ & & $7 / 8$ \\
\hline
\end{tabular}


Table 4. Cont

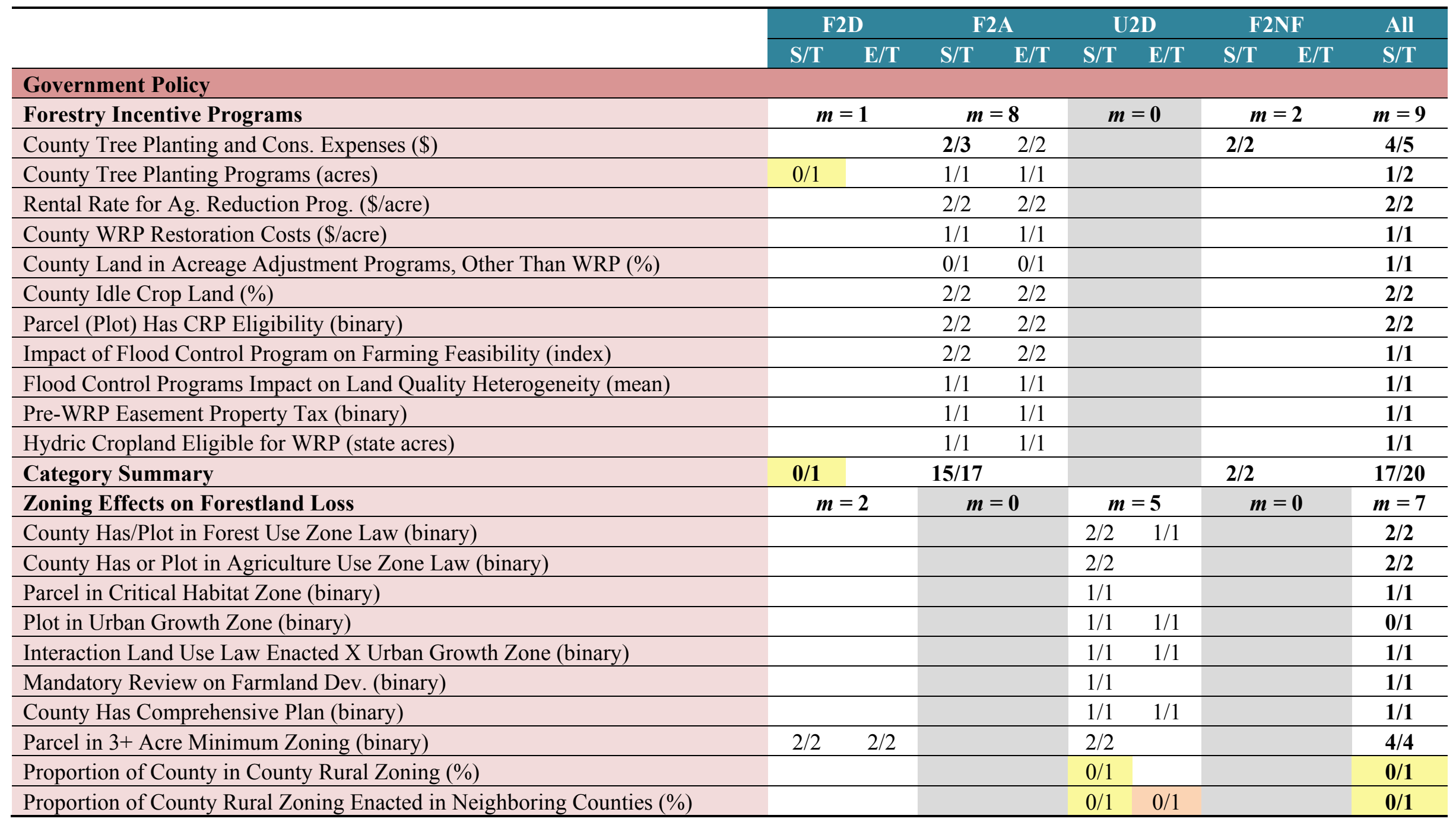


Table 4. Cont

\begin{tabular}{|c|c|c|c|c|c|c|c|c|c|}
\hline & \multicolumn{2}{|c|}{ F2D } & \multicolumn{2}{|c|}{ F2A } & \multicolumn{2}{|c|}{ U2D } & \multicolumn{2}{|c|}{ F2NF } & \multirow{2}{*}{$\frac{\text { All }}{\mathrm{S} / \mathrm{T}}$} \\
\hline & $\mathrm{S} / \mathrm{T}$ & $\mathrm{E} / \mathrm{T}$ & $\mathrm{S} / \mathrm{T}$ & $\mathrm{E} / \mathrm{T}$ & $\mathrm{S} / \mathrm{T}$ & $\mathrm{E} / \mathrm{T}$ & $\mathrm{S} / \mathrm{T}$ & $\mathrm{E} / \mathrm{T}$ & \\
\hline Proportion of County in Township Rural Zoning (\%) & & & & & $1 / 1$ & $1 / 1$ & & & $\mathbf{1} / \mathbf{1}$ \\
\hline Proportion of Township Rural Zoning Enacted in Neighboring Counties (\%) & & & & & $1 / 1$ & $1 / 1$ & & & $\mathbf{1} / \mathbf{1}$ \\
\hline Category Summary & $2 / 2$ & & & & $13 / 15$ & & & & 15/17 \\
\hline \multicolumn{10}{|l|}{ Site Characteristics } \\
\hline Land Quality/Productivity & \multicolumn{2}{|c|}{$m=19$} & \multicolumn{2}{|c|}{$m=17$} & \multicolumn{2}{|c|}{$m=8$} & \multicolumn{2}{|c|}{$m=9$} & $m=48$ \\
\hline $\begin{array}{l}\text { Average Site Productivity Rating For County (inversed LCC, MLRA Class, or } \\
\text { Site Index) }\end{array}$ & $3 / 13$ & $2 / 2$ & $11 / 11$ & $7 / 7$ & $2 / 2$ & $1 / 1$ & $2 / 4$ & $1 / 1$ & $18 / 30$ \\
\hline Variance in Average County LCC (derived estimate) & & & $1 / 1$ & $1 / 1$ & & & $1 / 1$ & $1 / 1$ & $2 / 2$ \\
\hline Highly Productive Soils-LCC I,II; MRLC Class 1,2 ( $\%$ of area or binary) & $8 / 14$ & $5 / 6$ & $7 / 12$ & $6 / 7$ & $4 / 5$ & & $4 / 6$ & $2 / 3$ & $23 / 37$ \\
\hline Moderately Productive Soils-LCC III,IV (\% of county, acreage, plot, or binary) & $1 / 1$ & $1 / 1$ & $2 / 2$ & $2 / 2$ & & & $2 / 2$ & $1 / 1$ & $5 / 5$ \\
\hline Loss of Highly Productive Acreage During Study Period (\%) & & & & & $1 / 1$ & & & & $\mathbf{1} / \mathbf{1}$ \\
\hline $\begin{array}{l}\text { Land Quality Fragmentation Index } \\
\text { (continuous, low value }=\text { low fragmentation, high value }=\text { high fragmentation) }\end{array}$ & & & & & $1 / 1$ & $1 / 1$ & & & $1 / 1$ \\
\hline Poor Soil for Development (binary) & & & & & $2 / 2$ & $1 / 1$ & & & $2 / 2$ \\
\hline FIA Plot or Raster Slope $(\%)$ & $4 / 4$ & $1 / 1$ & $2 / 2$ & & $2 / 3$ & $2 / 2$ & $2 / 3$ & $1 / 1$ & $10 / 12$ \\
\hline Elevation (meter) & $1 / 2$ & $1 / 1$ & & & & & & & $1 / 2$ \\
\hline Category Summary & $17 / 34$ & & $23 / 28$ & & $12 / 14$ & & $11 / 16$ & & $63 / 92$ \\
\hline Forestland Proximity Influences & $m=$ & & $m=$ & & $m=$ & & $m=$ & & $m=9$ \\
\hline Location Is Softwood Forest (binary) & $1 / 1$ & & $0 / 1$ & & & & & & $1 / 2$ \\
\hline Location Is Hardwood Forest (binary) & $0 / 1$ & & $0 / 1$ & & & & & & $\mathbf{0} / \mathbf{2}$ \\
\hline Contiguous Forest Area in Parcel or Around Plot (acres) & $2 / 2$ & & $1 / 1$ & & & & $1 / 1$ & $1 / 1$ & $4 / 4$ \\
\hline Forested Land In County (acres) & & & $1 / 1$ & $1 / 1$ & & & & & $\mathbf{1} / \mathbf{1}$ \\
\hline Public Ownership (binary or percent by area) & $0 / 1$ & & $0 / 1$ & & $0 / 1$ & $0 / 1$ & & & $\mathbf{0} / \mathbf{3}$ \\
\hline Location Is Industry Ownership (binary) & $0 / 1$ & & $0 / 1$ & & & & & & $\mathbf{0} / 2$ \\
\hline Location Is NIPF Ownership (binary) & $1 / 1$ & & $0 / 1$ & & & & & & $1 / 2$ \\
\hline
\end{tabular}


Table 4. Cont.

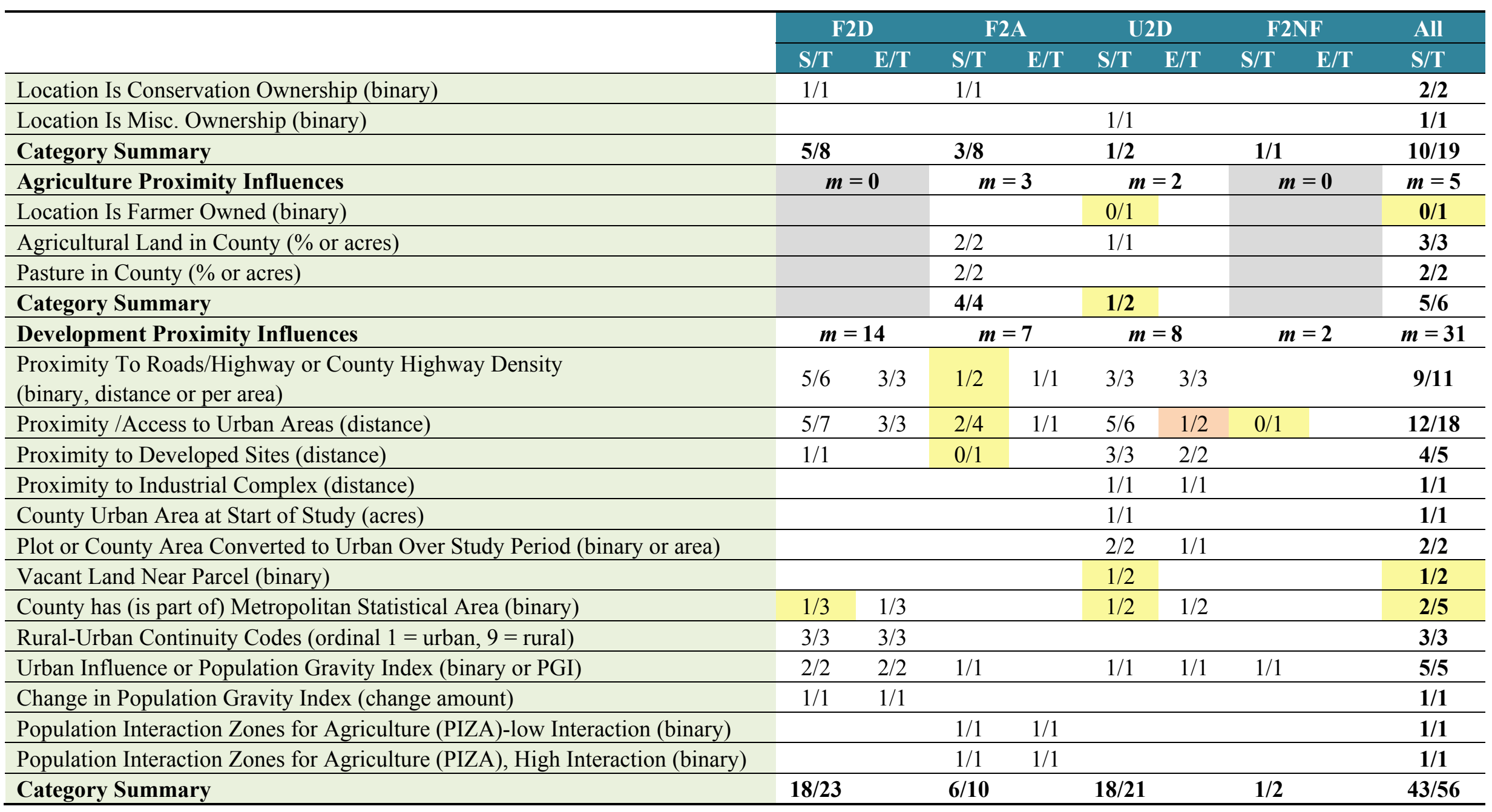


Table 4. Cont.

\begin{tabular}{|c|c|c|c|c|c|c|c|c|c|}
\hline & & & & & $\mathrm{U}$ & & F21 & & All \\
\hline & $\mathrm{S} / \mathrm{T}$ & $\mathrm{E} / \mathrm{T}$ & $\mathrm{S} / \mathrm{T}$ & $\mathrm{E} / \mathrm{T}$ & $\mathrm{S} / \mathrm{T}$ & $\mathrm{E} / \mathrm{T}$ & $\mathrm{S} / \mathrm{T}$ & $\mathrm{E} / \mathrm{T}$ & $\mathrm{S} / \mathrm{T}$ \\
\hline Socioeconomic Characteristics & & & & & & & & & \\
\hline Population and Growth & $m=$ & & & & & $=7$ & & $=11$ & $m=39$ \\
\hline County Population (people) & & & & & $1 / 1$ & & & & \\
\hline County Population Density (people/area unit or county) & $14 / 15$ & $9 / 10$ & $3 / 10$ & $2 / 3$ & $4 / 4$ & $2 / 2$ & $7 / 7$ & $2 / 2$ & $28 / 36$ \\
\hline Change in County Population or Density (\%) & $1 / 1$ & & & & $3 / 3$ & $1 / 1$ & $1 / 1$ & $1 / 1$ & $5 / 5$ \\
\hline Census Block Population Growth Rate (\%) & $0 / 1$ & & $0 / 1$ & & & & & & $0 / 2$ \\
\hline Change in Nearest Urban (or MSA) Population (\%) & & & & & & & $1 / 1$ & $1 / 1$ & $1 / \mathbf{1}$ \\
\hline County Pop./Forest acres (people/unit area) & $2 / 2$ & $2 / 2$ & & & & & & & $2 / 2$ \\
\hline Urban Population (people) & & & & & & & $3 / 3$ & $1 / 1$ & $\mathbf{3 / 3}$ \\
\hline Rural Population (people) & & & & & & & $0 / 3$ & & $\mathbf{0} / \mathbf{3}$ \\
\hline Category Summary & $17 / 19$ & & $3 / 11$ & & $8 / 8$ & & $12 / 15$ & & $39 / 52$ \\
\hline Income & & & & & & $=6$ & & $=5$ & $m=18$ \\
\hline County Average Salary, Per Capita Inc, Median HH Income (\$) & $4 / 5$ & $3 / 3$ & & & $4 / 4$ & $1 / 1$ & $5 / 5$ & & 13/14 \\
\hline Census Tract Median Household Income (\$) & $0 / 1$ & & $0 / 1$ & & & & & & $\mathbf{0} / 2$ \\
\hline County (or State) Change in Median Household Income (\%) & & & & & $0 / 1$ & & & & $\mathbf{0} / \mathbf{1}$ \\
\hline Poverty $(\%)$ & $1 / 2$ & & & & & & & & $1 / 2$ \\
\hline Inflation Rate (\%) & & & & & & & $0 / 1$ & & 0/1 \\
\hline Change in employment (city level) (\%) & & & & & $1 / 1$ & & & & $1 / 1$ \\
\hline Category Summary & $5 / 8$ & & $\mathbf{0} / \mathbf{1}$ & & $5 / 6$ & & $5 / 6$ & & $15 / 21$ \\
\hline Other Socioeconomic & & & & & & $=\mathbf{0}$ & & $=1$ & $m=7$ \\
\hline Landowner Age (years) & & & $1 / 1$ & $1 / 1$ & & & $\mathbf{0} / \mathbf{1}$ & & $1 / 2$ \\
\hline BS Degree or Higher (\%) & $3 / 3$ & & $0 / 1$ & & & & & & $3 / 4$ \\
\hline HS Degree $(\%)$ & $1 / 1$ & $1 / 1$ & & & & & & & $1 / 1$ \\
\hline Category Summary & $4 / 4$ & & $1 / 2$ & & & & $0 / 1$ & & $5 / 7$ \\
\hline
\end{tabular}

Variable coefficients significance were used for vote counting and summed across similar independent variable groups (i.e., "Soil Expectation Value") and categories (i.e., "Timber Rents") and organized by major econometric drivers (i.e., "Market Drivers"). Vote counts ratios S/T denotes the vote count of observed significant coefficients to the total coefficients within an independent variable group. Vote count ratios E/T denote the vote count of observed significant coefficient that met the study authors' expectations to all variables in a group that had expectations expressed. 
While Table 4 provides important information on success of independent variable groups, information about sign relationship was lost by not including the actual vote counts. These are in the accompanying dataset for detailed review. To avoid tedious discussion of sign relationship between variables and forestland loss for each model type, we have reserved discussion of sign relationship for certain successful variables until the conclusions section.

\section{Discussion}

Factors such as the variety of model specifications, data used, geographic location, unit scale and many others made summarizing this meta-analysis very challenging. Below, we have provided some trends and observations suggested by Table 3 about relative success of the observed variables. This discussion followed the organizational scheme of econometric drivers and categories.

\subsection{Market Drivers}

Market drivers were popular across all model types. Timber rents, agricultural rents, and agricultural costs/uncertainty were most popular categories for F2D, F2A, and N2NF models. Urban rents and urban costs/uncertainty were popular for F2D and U2D models. Soil expectation value (SEV) is the potential forest rent of a land unit (i.e., county) defined as the per-acre present discounted value of an infinite stream of timber revenues, typically by product class (sawtimber or pulpwood). Revenues are discounted based on timber volume at time of harvest (timber yield) and price of timber products. Timber yield relies on both site quality and timber rotation lengths that are controlled using the Faustmann rule at a 5\% discount rate. Agriculture SEV often equals the present discounted value of annual real per-acre net revenues from cropland and pasture. County-level estimates are often developed by summing weighted revenues of specific important crops in the county. SEV for all sawtimber dominated the forms of timber rents with a low success rate $(\mathrm{S} / \mathrm{T}=3 / 8)$ for F2D models. The low success rate in the F2D models did not appear to be tied to geographic region [32]. Many authors did not have a priori expectations about SEV for sawtimber in F2D models and many concluded that they are negligible compared to urban rents in these models [32,59,69]. However, many of the same studies found SEV for sawtimber an excellent predictive variable in F2A models $(\mathrm{S} / \mathrm{T}=8 / 10)$ as did F2NF models $(\mathrm{S} / \mathrm{T}=3 / 4)$. In F2A models, the expectation that timber income reduces probability of agricultural conversion was met $100 \%(\mathrm{E} / \mathrm{T}=8 / 8)$. Income from timber products and the stumpage value of sawtimber (used exclusively in the US South F2D models) was successful in both F2D and F2A models and met expectations when stated. Timber costs/uncertainty was only used in F2A and F2NF models but not often $(m=3)$ and with limited success.

Agriculture rents had very poor success $(\mathrm{S} / \mathrm{T}=5 / 16)$ in F2D models but were highly successful in the other three model types. County-level crop revenue data made available through the USDA Agricultural Census was the agriculture rent variable used most frequently. Some authors provided net crop production revenues (crop production revenues minus cropping costs) [2,58,59]. Others, specifically analyzing the effects of production costs, kept revenues and costs as separate variables $[10,12,43,45]$. In most cases, government payment programs to farmers were not included as rent. Lubowski [12] included government payments in crop revenues, assuming these have a stabilizing (insuring) effect on farmers' expectations of future returns. Agricultural rents typically were not expected to have a significant 
relationship in F2D models, but were often expected to be equally as important as timber rents in F2A models. This expectation was met in most cases.

The success of agriculture rents in U2D models $(\mathrm{S} / \mathrm{T}=2 / 3)$ may reflect the relative importance of prime agricultural land (included in "undeveloped" land) as land becomes developed [24,76]. Similarly, agriculture rents success in F2NF models may be attributed by the influence of prime agricultural land that are included in the "non-forested" class [33,71].

Agriculture costs/uncertainty estimates found success in F2A models ( $\mathrm{S} / \mathrm{T}=9 / 11)$. A wide variety of variables were represented in this category but with cropping costs and conversion from forest to agriculture used more frequently. Most results conformed to the study authors' expectations.

Urban rents were highly successful in F2D, U2D, and F2NF models, mostly in the form of profit from development (often median housing value) and residential land value. Expected positive relationships between urban rent and forestland loss were met when stated. Lubowski's [12] analysis showed that the significant positive relationship of urban rent in forest to urban transition lessened in regions of highly productive forestland.

Urban costs, used mostly in U2D models, included a variety of independent variable groups typically expected to reduce the probability of development. Value of farmland, conversion costs, and property taxes all were successful and met sign expectations in U2D models. Polyakov and Zhang [62] found property taxes a deterrent to forest development in a F2D model but suggested it may lead to higher probability of forest conversion to agriculture or other uses. Urban (development) uncertainty estimates effected risk assessment involved in development investment decisions. Sewer access was an incentive that reduces development risk, thus increasing the probability of development [73]. Variability in new housing value increased development risk thereby reducing the probability of development [47].

\subsection{Government Policy}

It is important to note that while government policy directly affects many other variables, we wanted to use studies that explicitly measured the effects of government policy of forestland loss or gain. Government policy drivers were used in 16 models in two categories and model types. F2A models focused on forestry incentive programs and U2D models on zoning effects on forestland loss. The category on forestry incentive programs provided a variety of successful independent variable groups $(\mathrm{S} / \mathrm{T}$ category summary $=15 / 16)$ that met study authors' expectations. F2A studies $[43,44,47]$ and F2NF studies [64] modeled county-level tree planting expenditures or acres to successfully predict landowner participation in farmland retirement rental programs like NRCS Conservation Reserve Program (CRP) or NRCS Wetland Reserve Program (WRP). Parks and Kramer [10] and Parks and Schorr [45] also successfully predicted participation in WRP or CRP using variables on program rental rates, restoration costs, acres of county lands already in other programs, or pre-WRP tax treatments. Stavins and Jaffe [48] studied variables describing the impacts of government flood control policies and successfully predicted the unintended effects these have on WRP land.

The zoning category (mostly in U2D models) involved diverse variable groups used with relative infrequency. This category, as a whole, also achieved a high success ratio for significance (S/T category summary $=13 / 16$ ) and usually met study authors' expectations. The effects of zoning 
regulations and land planning on development of forest and farmland received much attention through the works of Cho [24] and Kline and Alig [76]. Irwin et al. [74] modeled the effects county- and township-level rural zoning had on where development activities take place. They found strong evidence for "spill-over" effects where the proportion of rural township zoning ordinances increased development risk of adjacent counties. Independent variable groups for forestry incentive programs and zoning have excellent potential for future work in LULC change studies.

\subsection{Site Characteristics}

Site characteristics was the most popular and diverse of the econometric drivers. Determining a logical classification scheme for this meta-analysis proved difficult at times. The conceptual framework for site characteristics was on the basis of site conditions (quality, ownership) and/or spatial context in the landscape. No doubt, many variables in this set could logically be re-classified into other categories with obvious overlap, such as:

(1) crop and forestland productivity estimates (site characteristics) were related to timber and farm SEV and the value of farmland (markets)

(2) slope and elevation (site characteristics) were related to urban conversion costs (markets)

(3) forest types (site characteristics) were related to timber value (markets)

(4) ownership status of "conservation lands" (site characteristics) may be analogous to "critical habitat zone" (government policy)

(5) numerous variables estimating urban influences based on proximity (site characteristics) were directly tied with population and income levels (socioeconomic).

While these illustrate some of the classification "grey-areas" that existed, the site productivity and locational emphasis assigned to site characteristics allowed organization of its four categories. The first category was based on productivity conditions of the site and the other three were based on other site conditions and/or relative distances from LULC change influences.

Land quality/productivity represented the most frequently used category in all models analyzed. The most common estimates were based on county average estimates on soil productivity for cropland (LCC) or forestland (site class or site index). USDA NRCS provide Land Capability Class (LCC) rating for every soil series in the United States. This rating is in 8 ordinal classes (I-VIII). Classes I and II are considered the best and most highly productive soils. Classes III, IV are considered capable of producing cultivated crops with good management and conservation treatment. Classes V through VII are suited to perennial vegetative species (forest, orchard, pasture), and Class VIII soils are not suitable for managed vegetative production. "Site class" is by Munn and Cleaves [3] as "the land's potential timber yield measured in cubic feet/acre/year and is ranked from 1 (lowest) to 7 (highest)". "Site index" is an estimate of forest productivity based on tree height at a given age. More productive sites yield taller trees all else remaining equal.

Also popular, were estimates of highly productive agriculture soils (in county acres or percentages). In F2D models, these two popular independent variable groups had poor success achieving statistical significance $(\mathrm{S} / \mathrm{T}=3 / 13$ and $8 / 14$, respectively). This suggested that, similar to timber rents, site productivity (regardless of agricultural or forest productivity estimates) is not a successful predictor for 
forestland loss in F2D models. In F2A models, average county productivity was very successful and met all expectations. The highly productive soils variable group was less successful in F2A models $(\mathrm{S} / \mathrm{T}=7 / 12)$, yet, when stated, study authors' expectations of highly productive soils' sign relationships were usually met $(\mathrm{E} / \mathrm{T}=6 / 7)$.

Land productivity estimates, particularly in the form of highly productive soils were also successful in U2D and F2NF models. In both cases, this may be tied more to the relatively resiliency of highly productive croplands to development pressure when compared with forestland. Cho et al. [24] point out that higher value of prime farm land in the Western US out-weighed forestland value and led to forest loss when under development pressure. Bockstael [73] and Hsieh et al. [17] both found high farmland value was a deterrent to development in U2D models (seen in the urban costs/uncertainty category). Conversely, Bockstael [73] and Irwin et al. [74] found the variable group, poor soil for development, successful in U2D models. Other site factors effecting agriculture or development, such as slope and elevation, were successful all four model types.

Forestland proximity influences such as forest type and ownership appeared in both F2A and F2D model types but with limited success in F2D and even less in F2A. Importantly, the variable, contiguous forest area around the study parcel or plot, showed significance in three US South studies [3,42,50] with a negative relationship to forestland loss. Similarly, county agricultural land ownership (in the agricultural proximity influences category) showed success when used in F2A and U2D models.

Urban proximity influences used numerous distance-based estimates but also contained derived estimations of "urban influence" over the adjacent landscape. Proximity estimates such as distance to roads, urban areas, developed sites, and industrial complexes were very successful in both F2D and U2D models meeting expectation in most cases. In F2A models, there was less success suggesting that, all else remaining the same, distances alone to urban areas may not strongly influence forest to agriculture conversion. In both F2D and U2D models, the poor success of variables estimating the detection of a county's presence in Metropolitan Statistical Areas (MSAs) supports this point.

There are some relatively recent sets of derived estimates from the USDA Economic Resource Center's (ERS) that have shown promise. One set used successfully in F2D models by Nagubadi and Zheng [53-55] were the Rural-Urban Continuum Codes (RUC) [79]. These index codes were related to the size of urban areas and the degree of urbanization in non-urban areas. Another ERS dataset used was the Urban Influence (UI) Codes that incorporated distance, income, and population [80]. Landis and Zhang [77] used UI Codes in an U2D model and Lewis and Plantinga [68] used UI codes in a F2NF model. Both efforts had success using the variable. Population Gravity Indices (PGI), similar to UI Codes, were derived in individual studies by Kline et al. [51] and Polyakov and Zhang [63] and were based on distance to urban areas, and urban population. PGI was successful $(\mathrm{S} / \mathrm{T}=4 / 4)$ in the US South for F2D and F2A models, indicating the potential importance of this variable.

In a F2A model, Jensen [44] applied ERS Population Interaction Zones for Agriculture (PIZA) [81] for prediction of cropland to conversion to forested CRP in North Carolina. PIZA is an agricultural-based population gravity index derived from interactions between agricultural production activities nearby urban populations. The success met with this variable holds promise for further F2A studies. 


\subsection{Socioeconomic Characteristics}

This class included two popular categories, population and income, and some lesser used independent variable groups estimating education and landowner age. Population density was the most frequently successful forestland change predictor of all variable groups in this meta-analysis. However, success was limited to F2D, U2D, and F2NF models types $(S / T=25 / 26)$. This data supports the generally accepted observations of Alig [65] and Alig and Healy [82] that population and income are two of the most important predictors of urban build-up of forests and undeveloped land. Census block populations did not appear to have the same success [3]. F2A models had very low success $(\mathrm{S} / \mathrm{T}=3 / 11)$ suggesting population alone is a poor predictor of forest to agriculture conversion.

Income, particularly county level average salary, per capita, or median household income, had strong success in F2D, U2D and F2NF models but was virtually unused in F2A models. Other forms of income used did not share the same success as the county-level estimates. Landowner age had apparent success in F2A models. Education levels, whether high school or college degree, showed high success in F2D models.

\section{Conclusions: Recommendation of Independent Variables by Model Type}

Over the past $30+$ years, econometric modeling of LULC change has provided tools for identifying the drivers useful in predicting forestland change. Literature reviews provide summaries of successful independent variables used in this field of econometric modeling. However, we believe we have developed the first meta-analysis that provides an organized approach to defining success of forest LULC change independent variables in recent and important econometric study models.

We found four basic model types predicting forestland (or forests as part of undeveloped land) change to agriculture, development, or non-forestland. These models were summarized by model type below with recommendations on categories and notable independent variable groups. Table 5 provides the studies that we suggested for each category based on the $67 \%$ "S/T" success ratios results. The citations listed direct the reader to studies that had success with a variable listed in that category and model type. The studies listed did not necessarily experience the same success with all variables in their models.

\subsection{Forest to Agriculture Models}

There were 21 F2A models with 12 occurring in the US South. As a group, these models made excellent use of all forms of timber and agriculture rent variables. Timber rents typically had negative relationships with forestland loss while agriculture rents had positive relationships, as might be expected. Timber and agriculture cost and uncertainty variables also achieved high success in this model type, particularly in conversion and production costs. Shatzki's [47] work successfully showed uncertainty estimates of forest and agriculture revenues drive use change decisions. Urban rents were not considered in F2A models used in this study, possibly owing to unclear relationships urban rents have in F2A models. Government policy variables predicting forestland increase through farmland retirement or other (i.e., flood control) programs have had excellent success, but zoning ordinance effects on forest to agriculture conversion have not received the same attention. 
Table 5. Suggested econometric studies that contained successful predictive independent variables in four forestland loss model types. Studies are identified by citation number and organized by major econometric drivers and categories of independent variable types.

\begin{tabular}{|c|c|c|c|c|c|}
\hline Driver & Category & $\begin{array}{c}\text { F2D } \\
\text { Studies } \\
\end{array}$ & F2A Studies & U2D Studies & F2NF Studies \\
\hline \multirow{6}{*}{ 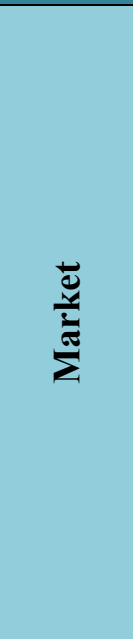 } & Timber Rents & $\begin{array}{c}{[2,12,49,} \\
52-55,57-60,62] \\
\end{array}$ & $\begin{array}{l}{[2,12,32,41,43,} \\
47,58,59,62,71]\end{array}$ & & $\begin{array}{c}{[33,64,} \\
66-69,71] \\
\end{array}$ \\
\hline & $\begin{array}{c}\text { Timber } \\
\text { Costs/Uncertainty }\end{array}$ & \multicolumn{3}{|c|}{$[47]$} & {$[67]$} \\
\hline & Agriculture Rents & {$[49,59,61]$} & $\begin{array}{c}2,10,12,32,41 \\
43,44,47,58 \\
60-62,71]\end{array}$ & {$[24,72]$} & {$[33,69,71]$} \\
\hline & $\begin{array}{l}\text { Agriculture } \\
\text { Uncertainty }\end{array}$ & & \multirow[t]{2}{*}[43,45,47,62]{} & {$[24]$} & \\
\hline & Urban Rents & {$[53-55,57,62]$} & & {$[24,73]$} & {$[67,68]$} \\
\hline & $\begin{array}{c}\text { Urban } \\
\text { Costs/Uncertainty }\end{array}$ & [62] & \multirow{2}{*}{\multicolumn{2}{|c|}{$\begin{array}{c}{[10,41,} \\
44-46,48]\end{array}$}} & \\
\hline \multirow{2}{*}{ 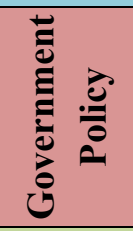 } & $\begin{array}{l}\text { Forestry Incentive } \\
\text { Programs }\end{array}$ & & & & [64] \\
\hline & $\begin{array}{l}\text { Zoning Effects on } \\
\text { Forestland Loss }\end{array}$ & {$[54,57]$} & & {$[16,24,75,76]$} & \\
\hline \multirow{4}{*}{ 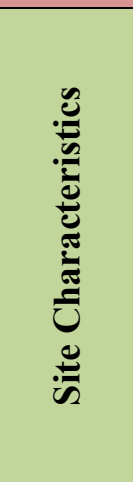 } & $\begin{array}{c}\text { Land } \\
\text { Quality/Productivity }\end{array}$ & $\begin{array}{l}{[2,3,12,49} \\
51-59,63]\end{array}$ & $\begin{array}{c}{[2,3,12,32,} \\
43-45,47, \\
58-61,63,71]\end{array}$ & $\begin{array}{c}{[14,16,17,24,} \\
73,74,77]\end{array}$ & $\begin{array}{c}{[33,42,} \\
66-69,71]\end{array}$ \\
\hline & $\begin{array}{l}\text { Forestland Proximity } \\
\text { Influences }\end{array}$ & {$[3,50,63]$} & {$[3,41,63]$} & {$[76]$} & [42] \\
\hline & $\begin{array}{c}\text { Agricultural } \\
\text { Proximity Influences }\end{array}$ & & {$[41,44,47]$} & {$[14]$} & \\
\hline & $\begin{array}{c}\text { Development } \\
\text { Proximity Influences }\end{array}$ & $\begin{array}{l}{[3,32,49-51} \\
53-57,59,63]\end{array}$ & $\begin{array}{c}{[32,44,59,} \\
59,63]\end{array}$ & $\begin{array}{c}{[14,16,17,24,} \\
72,74,75,77]\end{array}$ & [68] \\
\hline \multirow{3}{*}{ 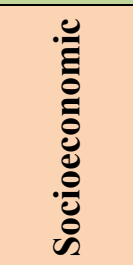 } & $\begin{array}{c}\text { Population and } \\
\text { Growth }\end{array}$ & $\begin{array}{c}{[2,3,32,} \\
49-53,55,57-61]\end{array}$ & \multirow[t]{2}{*}[3,47,59]{} & $\begin{array}{c}{[14,16,17,72,} \\
74,76,77]\end{array}$ & $\begin{array}{c}{[33,42,} \\
64-67,69-71]\end{array}$ \\
\hline & Income & {$[52-55,57]$} & & {$[17,24,72,77]$} & [64-67] \\
\hline & $\begin{array}{c}\text { Other } \\
\text { Socioeconomic }\end{array}$ & {$[3,53-55]$} & {$[10]$} & & \\
\hline
\end{tabular}

Site characteristics, while used frequently in all model types, had uniquely high success in F2A models. Average county soil productivity was a key variable in predicting forest to farmland conversion. Some caution may be needed using the independent variable group, highly productive soils, since this group did not have a high success ratio. Slope was a successful predictor in F2A (and all) model types. Forest and agriculture land contiguity both were successful predictors in F2A models. But, only a few proximity variables dealing with urban influences had success. Of these, PIZA estimates, used by Jensen [44] showed promise in future F2A studies, perhaps as a suitable surrogate for population. Socioeconomic variables performed poorly in the F2A models but those with success are listed in 
Table 5. The success of landowner age by Parks and Kramer [10] suggested its future use, particularly when the effects of generational changes are considered.

\subsection{Forest to Development Models}

Of the 21 F2D models, 15 were in US South, and 10 F2D models were from the same studies as F2A models. Interestingly, timber SEV (tied to land productivity) had lower success that other forms of timber rents such as timber products income or stumpage value of all sawtimber. Agricultural rents had very poor success suggesting this category is a poor choice in F2D modeling. Timber and agricultural costs/uncertainty were not given attention in the F2D studies used. Urban rents and costs/uncertainty both were very successful, particularly with housing values (positive relationship to forestland loss), property taxes, and forest to urban conversion costs (both with negative relationships to forestland loss). Government policy had been virtually ignored in this model type with the exception of zoning parcel size minimum used by Nagubadi and Zhang [54] and Zhang and Nagubadi [57]. In the site characteristics category, soil quality had very low statistical success suggesting caution about the use of these variables in F2D models.

Within forestland proximity influence category, variables estimating county forestland or contiguity were successful in F2D models. Distance to urban amenities successfully predicted a negative relationship with forest development in F2D models. For this model type, estimates like UI, PGI, and RUC indices showed strong promise for future work. County population density and income were excellent variables in F2D modeling, as would be expected. Poverty, used by Nagubadi and Zhang [55], met expectations as a predictor of forestland retention in the US South.

\subsection{Undeveloped to Developed Models}

None of the 10 U2D models occurred in the US South and timber production was emphasized less as it was grouped with forest uses (including "green space") and agriculture. This was evidenced by lack of interest in variables estimating timber or agriculture rents/costs, and forestry incentive programs and strong interest in urban rents, urban costs/uncertainty, and zoning regulations. Both urban rents and costs/uncertainty were important and successful categories that met authors' expectations. Forest zoning variables were popular, diverse, and successful ( $\mathrm{S} / \mathrm{T}$ category summary $=13 / 16)$. Interactions of zoning ordinances play an important role in the fate of maintaining forestland [76]. Sometimes, regional ordinances designed to reduce development may create spill-over effects in adjacent regions [74] effecting working forest-use there. Rural ordinances and zoning regarding protection of working forests are likely to increase over time and have extremely important implications for future timber management.

Like F2A models, U2D models had strong success using most site productivity variables. County percentage of highly productive soils was successful $(\mathrm{S} / \mathrm{T}=4 / 5)$, unlike F2D and F2A models. This relates to the value placed on prime agriculture land in rapidly urbanizing regions. Like all other model types predicting development, slope was a deterrent for development. Proximity estimates for forestland and agriculture were not used with much success, owing, at least, to the fact that forest and farm land are not differentiated. However, urban land proximity and influences were very successful in U2D models, particularly distance estimates to urban amenities. Landis and Zhang [77] offered the 
only U2D model with urban influence estimates and it showed promise for future work. Population and income were also important successful predictors.

\subsection{Forest to Non-Forest Models}

These model predicted change from forestland into some other use, typically agriculture or development. Nine of the 12 F2NF models occurred in the US South. Timber rent variables used had poor success, warranting caution in F2NF models. Timber SEV had a significant but unexpected sign relationships [71] with forestland loss giving it a poor expectation ratio $(E / T=2 / 4)$. Variables in the agricultural and urban rent categories were not frequent but appeared more successful. These had a positive relationship with forestland loss, as would be expected. County tree planting expenses proved a successful predictor of forestland gain in two US South models (Alig et al. [64]). In many respects, F2NF models were similar to F2D models. However, an important distinction was that independent variable groups in the soil productivity category appeared more successful than F2D models. One reason for this may be due to the relationship between soil productivity and forest/agriculture conversion that exists in the F2NF model type. The relatively high success for soil productivity suggests that F2NF models may be expected perform well with this variable group. Population and income both were successful and seem good choices in F2NF models.

\subsection{Important Considerations}

It is important to understand this meta-analysis included a wide variety of study objectives, methodologies and US regions. The observations and recommendations made resulting from this meta-analysis should be tempered by the diversity of studies used. The recommendations should be viewed as a guide to the most helpful variables given a modeling project. The success of a particular chosen variable depends on the modeling methodologies adapted to the user's application. Therefore, it is important to carefully research the exact data sources, methods, and geographic regions for the recommended categories. We provide some information regarding these in the accompanying data files but they are no substitute for researching each study's methods prior to taking the time and effort to select successful independent variables.

Land use change will become increasingly more dramatic over the next 50 years. The need to determine the factors that cause these changes at the national, regional, and local level will also grow in importance as markets, policies, and socioeconomics evolve. Identifying those variables that increase chances of successful prediction is a progression that required numerous attempts from many studies. This meta-analysis helps further the work of these studies by developing an organized process of identifying the success of popular, less popular, and relatively new econometric variables that will aid future research efforts. We realize there are numerous methods of classification resulting in different success ratios and the data made available can be classified as the user sees fit.

\section{Author Contributions}

James Jeuck, in partial fulfillment of his $\mathrm{PhD}$ requirements conducted the study under the guidance of his graduate committee, the other contributing authors for this paper. Jeuck performed the majority 
of the work involved in developing the scope of the study, methodology, analysis and basic reporting of the information. The other contributing authors all provided insight and advice into the each aspect of the project and helped Jeuck form a manageable solution to analyzing and summarizing the diverse nature of the dataset involved. All contributing authors assisted in the layout and editing of this paper.

\section{Conflicts of Interest}

The authors declare no conflict of interest.

\section{References}

1. U.S. Department of Agriculture Forest Service. Future of America's Forests and Rangelands: Forest Service 2010 Resources Planning Act Assessment; General Technical Report WO-87; USDA Forest Service: Washington, DC, USA, August 2012; p. 198.

2. Ahn, S.; Plantinga, A.J.; Alig, R.J. Historical Trends and Projections of Land Use for the South-Central United States; Research Paper PNW-RP-530; U.S. Department of Agriculture, Forest Service, Pacific Northwest Station: Portland, OR, USA, March 2001; p. 20.

3. Munn, I.A.; Cleaves, D. An Analysis of Losses to the Southern Commercial Timberland Base. In Proceedings of the 1998 Southern Forest Economics Workshop (SOFEW), No. FO-906, Forest and Wildlife Research Center, The International Society of Forest Resource Economics, Mississppi State University, Starkville, MS, USA, April 1999; p. 7.

4. McDonald, R.I.; Motzkin, G.; Bank, M.S.; Kittredge, D.B.; Burk, J.; Foster, D.R. Forest Harvesting and Land-use Conversion over Two Decades in Massachusetts. For. Ecol. Manag. 2006, 227, 31-41.

5. Wear, D.N.; Newman, D.H. The Speculative Shadow over Timberland Values in the US South. J. For. 2004, 102, 25-31.

6. Mills, K.N.; Dicks, M.R.; Lewis, D.K.; Moulton, R.J. Measuring the Effect of Land Use Changes on Timber Production. In Proceedings of the 1994 Southern Forest Economics Workshop (SOFEW): 1994 Forest Economics on the Edge, The International Society of Forest Resource Economics, Mississppi State University, Starkville, MS, USA, March 1994; pp. 108-118.

7. Chen, H.; Tian, H.; Liu, M.; Melillo, J.; Pan, S.; Zhang, C. Effect of Land-cover Change on Terrestrial Carbon Dynamics in the Southern United States. J. Environ. Qual. 2002, 35, $1533-1547$.

8. Díaz, G.I.; Nahuelhual, L.; Echeverría, C.; Marín, S. Drivers of Land Abandonment in Southern Chile and Implications for Landscape Planning. Landsc. Urban Plan. 2011, 99, 207-217.

9. He, J.; Lang, R.; Xu, J. Local Dynamics Driving Forest Transition: Insights from Upland Villages in Southwest China. Forests 2014, 5, 214-233.

10. Parks, P.J.; Kramer, R.A. A Policy Simulation of the Wetlands Reserve Program. J. Environ. Econ. Manag. 1995, 28, 223-240.

11. Claassen, R.; Tegene, A. Agricultural Land Use Choice: A Discrete Choice Approach. Agric. Resour. Econ. Rev. 1999, 1, 26-36. 
12. Lubowski, R.N. Determinants of Land-Use Transitions in the United States: Econometric Analysis of Changes among the Major Land-Use Categories, Committee on Higher degrees in Political Economy and Government. Ph.D. Thesis, Harvard University, Cambridge, MA, USA, May 2002; p. 287.

13. Lubowski, R.N.; Plantinga, A.J.; Stavins, R.N. Land-use Change and Carbon Sinks: Econometric Estimation of the Carbon Sequestration Supply Function. J. Environ. Econ. Manage. 2006, 51, $135-152$.

14. Alig, R.J.; Lewis, D.J.; Swenson, J.J. Is Forest Fragmentation Driven by the Spatial Configuration of Land Quality? For. Ecol. Manag. 2005, 217, 266-274.

15. Butsic, V.; Lewis, D.J.; Ludwig, L. An Econometric Analysis of Land Development with Endogenous Zoning. Land Econ. 2011, 87, 412-432.

16. Carrion, C.; Irwin, E.G. Using a Spatial Economic Model of Land Use Conversion to Explain Residential Sprawl at the Rural-Urban Fringe. Am. J. Agric. Econ. 2004, 86, 889-904.

17. Hsieh, W.-H.; Irwin, E.G.; Forster, D.L. Spatial Dependence among County-level Land Use Changes. In Proceedings of the American Agricultural Economics Association 2000 Annual Meeting (New Name 2008: Agricultural and Applied Economics Association), Tampa, FL, USA, 30 July-2 August 2000; p. 27.

18. Carrión-Flores, C.; Irwin, E.G. Identifying Spatial Interactions in the Presence of Spatial Error Autocorrelation: An Application to Land Use Spillovers. Resour. Energy Econ. 2010, 32, $135-153$.

19. Liu, X.; Lynch, L. Do Agricultural Land Preservation Programs Reduce Farmland Loss? Evidence from a Propensity Score Matching Estimator. Land Econ. 2011, 87, 183-201.

20. Lichtenberg, E.; Tra, C.; Hardie, I. Land Use Regulation and the Provision of Open Space in Suburban Residential Subdivisions. J. Environ. Econ. Manage. 2007, 54, 199-213.

21. Lewis, D.J. Open Space Issues at the Rural-Urban Fringe: Discussion. Am. J. Agric. Econ. 2009, 91, 1326-1327.

22. Poudyal, N.C.; Hodges, D.G.; Tonn, B. Valuing Diversity and Spatial Pattern of Open Space Plots in Urban Neighborhoods. In Proceedings of the 2008 Southern Forest Economics Workers Annual Meeting, Savannah, GA, USA, 9-11 March 2008; Siry, J., Izlar, B., Bettinger, P., Harris, T., Tye, T., Baldwin, S., Merry, K., Eds.; The International Society of Forest Resource Economics: Mississppi State University: Starkville, MS, USA, March 2009; pp. 277-282.

23. Plantinga, A.J.; Lubowski, R.N.; Stavins, R.N. The Effects of Potential Land Development on Agricultural Land Prices. Resour. Futur. Discuss. Pap. 2002, 33, 2-11.

24. Cho, S.; Wu, J.; Alig, R. Land Development Under Regulation: Comparison between the East and West Sides of the Cascade Range in Oregon, Washington, and California. RURDS 2005, 17, $1-17$.

25. Jaeger, W.K.; Plantinga, A.J.; Grout, C. How has Oregon's Land Use Planning System Affected Property Values? Land Use Policy 2012, 29, 62-72.

26. Gosnell, H.; Kline, J.D.; Chrostek, G.; Duncan, J. Is Oregon's Land Use Planning Program Conserving Forest and Farm Land? A Review of the Evidence. Land Use Policy 2011, 28, 185-192. 
27. Grout, C.A.; Jaeger, W.K.; Plantinga, A.J. Land-use Regulations and Property Values in Portland, Oregon: A Regression Discontinuity Design Approach. Regul. Sci. Urban Econ. 2011, 41, 98-107.

28. Chamblee, J.F.; Colwell, P.F.; Dehring, C.A.; Depken, C.A. The Effect of Conservation Activity on Surrounding Land Prices. Land Econ. 2011, 87, 453-472.

29. Clark, J.K.; McChesney, R.; Munroe, D.K.; Irwin, E.G. Spatial Characteristics of Exurban Settlement Pattern in the United States. Landsc. Urban Plan. 2009, 90, 178-188.

30. Mendelsohn, R.; Dinar, A. Land Use and Climate Change Interactions. Annu. Rev. Resour. Econ. 2009, 1, 309-332.

31. Plantinga, A.; Mauldin, T.; Miller, D.J. An Econometric Analysis of the Costs of Sequestering Carbon in Forests. Am. J. Agric. Econ. 1999, 81, 812-824.

32. Plantinga, A.J.; Mauldin, T. A Method for Estimating the Cost of $\mathrm{CO}_{2}$ Mitigation through Afforestation. Clim. Change 2001, 49, 21-40.

33. Plantinga, A.J.; Wu, J. Co-benefits from Carbon Sequestration in Forests: Evaluating Reductions in Agricultural Externalities from an Afforestation Policy in Wisconsin. Land Econ. 2003, 79, 74-85.

34. Parks, P.J.; Hardie, I.W. Least-cost Forest Carbon Reserves: Cost-effective Subsidies to Convert Marginal Agricultural Land to Forests. Land Econ. 1995, 71, 122-136.

35. Turner, B.L.; Lambin, E.F.; Reenberg, A. The Emergence of Land Change Science for Global. PNAS 2007, 104, 20666-20672.

36. Plantinga, A.J.; Alig, R.; Cheng, H. The Supply of Land for Conservation Uses: Evidence from the Conservation Reserve Program. Resour. Conserv. Recycl. 2001, 31, 199-215.

37. Irwin, E.G.; Isserman, A.M.; Kilkenny, M.; Partridge, M.D. A Century of Research on Rural Development and Regional Issues. Am. J. Agric. Econ. 2010, 92, 522-553.

38. Beach, R.H.; Pattanayak, S.K.; Yang, J.-C.; Murray, B.C.; Abt, R.C. Econometric Studies of Non-industrial Private Forest Management: A Review and Synthesis. For. Policy Econ. 2005, 7, 261-281.

39. Pattanayak, S.; Mercer, D.E.; Sills, E.; Yang, J.-C. Taking Stock of Agroforestry Adoption Studies. Agrofor. Syst. 2003, 57, 173-186.

40. Lund, H. When is a Forest not a Forest? J. For. 2002, 100, 21-28.

41. White, F.C.; Fleming, F.N. An Analysis of Competing Land Uses. South. J. Agric. Econ. 1980, 12, 99-104.

42. Meng, L. Land-use Changes, Forest Type Changes, and Related Environmental Concerns in the Southern U.S. Ph.D. Thesis Auburn University, Auburn, AL, USA, 9 May 2011; p. 115.

43. Claassen, R.L. Rural Land Use in South Carolina 1982-1987: A Discrete Choice Approach, Master's Thesis, University of Maryland, College Park, MD, USA, May 1993; p. 77.

44. Jensen, J. Land Conversion and the Conservation Reserve Program (CRP) in North Carolina, Master's Thesis, Nicholas School of the Environment and Earth Sciences of Duke University, Durham, NC, USA, May 2007; pp. 34-35.

45. Parks, P.J.; Schorr, J.P. Sustaining Open Space Benefits in the Northeast: An Evaluation of the Conservation Reserve Program. J. Environ. Econ. Manag. 1997, 32, 85-94. 
46. Poe, G.L. Property Tax Distortions and Participation in Federal Easement Programs: An Exploratory Analysis of the Wetlands Reserve Program. Agric. Resour. Econ. Rev. 1998, 27, 117-124.

47. Schatzki, T. Options, Uncertainty and Sunk Costs: J. Environ. Econ. Manag. 2003, 46, 86-105.

48. Stavins, R.N.; Jaffe, A.B. Unintended Impacts of Public Investments on Private Decisions: The Depletion of Forested Wetlands. Am. Econ. Rev. 1990, 80, 337-352.

49. Ahn, S.; Abt, R.C.; Plantinga, A.J. Land Use in the South Central United States: A Further Investigation on Land Use Practices by Forestland Ownership. In Proceedings of the Southern Forest Economics Workshop 2002, The International Society of Forest Resource Economics, Mississppi State University: Starkville, MS, USA, March 2002; pp. 165-171.

50. Hodges, D.G.; Gunter, J.T.; Swalm, C.M.; Regens, J.L. Assessing the Impact of Urbanization on Timberland Availability in Southeastern Louisiana. In Proceedings of the 2nd Southern Forestry GIS Conference, Athens, GA, USA, 28-29 October 1998; p. 8.

51. Kline, J.D.; Moses, A.; Azuma, D.; Gray, A. Evaluating Satellite Imagery-Based Land Use Data. West. J. Appl. For. 2009, 24, 214-222.

52. Nagubadi, R.V.; Zhang, D. Determinants of Timberland Use by Ownership and Forest Type in Alabama and Georgia. J. Agric. 2005, 37, 173-186.

53. Nagubadi, R.; Zhang, D. Urbanization and Timberland-use Change in the Southern USA. In Cross-Sectoral Policy Developments in Forestry; Dube, Y., Schmithusen, F., Eds.; FAO and CAB International: Rome, Italy, 2007; pp. 212-224.

54. Nagubadi, R.V.; Zhang, D. Timberland Ownership in the Southern United States: Urbanization and Socio-economic Factors. In Proceedings of the 2008 Southern Forest Economics Workers Annual Meeting, Savannah, GA, USA, 9-11 March 2008; Siry, J., Izlar, B., Bettinger, P., Harris, T., Tye, T., Baldwin, S., Merry, K., Eds.; The International Society of Forest Resource Economics, Mississppi State University: Starkville, MS, USA, March 2009; pp. 10-17.

55. Nagubadi, R. V; Zhang, D. Class: A Modified Multinomial Logit Analysis. South. J. Appl. For. 2010, 34, 101-109.

56. Wear, D.N.; Bolstad, P. Land-Use Changes in Southern Appalachian Landscapes: Spatial Analysis and Forecast Evaluation. Ecosystems 1998, 575-594.

57. Zhang, D.; Nagubadi, R.V. The Influence of Urbanization on Timberland Use by Forest Type in the Southern United States. For. Policy Econ. 2005, 7, 721-731.

58. Ahn, S.; Plantinga, A.J.; Ralph, J. Alig Predicting Future Forestland Area: A Comparison of Econometric Approaches. For. Sci. 2000, 46, 363-376.

59. Ahn, S.; Plantinga, A.; Alig, R.J. Determinants and Projections of Land Use in the South Central United States. South. J. Appl. For. 2002, 26, 78-84.

60. Mauldin, T.E.; Plantinga, A.J.; Alig, R.J. Determinants of Land Use in Maine with Projections to 2050. N. J. Appl. For. 1999, 16, 82-88.

61. Mauldin, T.E.; Plantinga, A.J.; Alig, R.J. Land Use in the Lake States Region: An Analysis of Past Trends and Projections of Future Changes; PNW-RP-519; USFS Pacific Northwest Research Station: Portland, OR, USA, July 1999; p. 24. 
62. Polyakov, M.; Zhang, D. Property taxes: do they affect forestry and agricultural land uses? In Proceedings of the Southern Forest Economics Workshop 2006 Emerging Issues in Forest Economics Knoxville, TN, USA, 22-24 March 2006; Hodges, D.G., Ed.; The International Society of Forest Resource Economics, Mississppi State University: Starkville, MS, USA, March 2006, pp. 134-142.

63. Polyakov, M.; Zhang, D. Population Growth and Land Use Dynamics along Urban-Rural Gradient. J. Agric. Appl. Econ. 2008, 40, 649-666.

64. Alig, R.J.; White, F.C.; Murray, B.C. Economic Factors Influencing Land Use Changes in the South-Central United States; USDA Forest Service SEFES Research Papaper SE-272; USFS Southeastern Forest Experiment Station: Asheville, NC, USA, 1988; p. 26.

65. Alig, R. Econometric Analysis of the Factors Influencing Forest Acreage trends in the Southeast. For. Sci. 1986, 32, 119-134.

66. Hardie, I.W.; Parks, P.J. Land Use with Heterogeneous Land Quality: An Application of an Area Base Model. Am. J. Agric. Econ. 1997, 79, 299.

67. Hardie, I.; Parks, P.; Gottleib, P.; Wear, D. Responsiveness of rural and urban land uses to land rent determinants in the US South. Land Econ. 2000, 76, 659-673.

68. Lewis, D.J.; Plantinga, A.J. Policies for Habitat Fragmentation: Combining Econometrics with GIS-based Landscape Simulations. Land Econ. 2007, 83, 109-127.

69. Parks, J.; Murray, B.C. Land Attributes and Land Allocation: Nonindustrial Forest Use in the Pacific Northwest. For. Sci. 1994, 40, 558-575.

70. Wear, D.N.; Liu, R.; Foreman, M.; Sheffield, R.M. The Effects of Population Growth on Timber Management and Inventories in Virginia. For. Ecol. Manag. 1999, 118, 107-115.

71. Plantinga, A.; Ahn, S. Efficient Policies for Environmental Protection: An Econometric Analysis of Incentives for Land Conversion and Retention. J. Agric. Resour. Econ. 2002, 27, 128-145.

72. Alig, R.J.; Kline, J.D.; Lichtenstein, M. Urbanization on the US Landscape: Looking Ahead in the 21st Century. Landsc. Urban Plan. 2004, 69, 219-234.

73. Bockstael, N. Modeling Economics and Ecology: The Importance of a Spatial Perspective. J. Agric. Econ. 1996, 78, 1168-1180.

74. Irwin, E.G.; Hsieh, W.; Libby, L. The Effect of Rural Zoning on the Spatial Allocation of Urban Land. In Proceedings of the Effect of Rural Zoning on the Allocation of Land Use in Ohio, Selected Paper Presented at the 2001 American Agricultural Economics Association Meeting, Chicago, IL, USA, 3-7 August 2001; p. 24.

75. Irwin, E.; Bockstael, N.E. Interacting agents, spatial Externalities and the evolution of residential land use patterns. J. Econ. Geogr. 2002, 2, 31-54.

76. Kline, J.D.; Alig, R.J. Does Land Use Planning Slow the Conversion of Forest and FarmLands? Growth Change 1999, 30, 3-22.

77. Landis, J.; Zhang, M. Modeling Urban Land Use Change: The Next generation of the California Urban Futures Model. Available online: http:/www.ncgia.ucsb.edu/conf/landuse97/papers/ landis_john/paper.html (accessed on 6 March 2014).

78. Coulston, J.; Reams, G.; Wear, D.; Brewer, C. An Analysis of Forest Land Use, Forest Land Cover and Change at Policy-Relevant Scales. Forestry 2014, 87, 1-10. 
79. USDA ERS USDA Economic Research Service: Rural-Urban Continuum Codes. Available online: http://www.ers.usda.gov/data-products/rural-urban-continuum-codes/documentation.aspx (accessed on 6 March 2014).

80. USDA ERS USDA Economic Research Service-Urban Influence Codes. Available online: http://www.ers.usda.gov/data-products/urban-influence-codes/documentation.aspx (accessed on 6 March 2014).

81. USDA ERS USDA Economic Research Service-Population-Interaction Zones for Agriculture (PIZA). Available online: http://www.ers.usda.gov/data-products/population-interaction-zonesfor-agriculture-(piza)/documentation.aspx (accessed on 6 March 2014).

82. Alig, R.J.; Healy, R.G. Urban and Built-Up Land Area Changes in the United States: An Empirical Investigation of Determinants. Land Econ. 1987, 63, 215.

(C) 2014 by the authors; licensee MDPI, Basel, Switzerland. This article is an open access article distributed under the terms and conditions of the Creative Commons Attribution license (http://creativecommons.org/licenses/by/3.0/). 